\title{
Zarys stosunków rolniczych Lubelszczyzny na przełomie XVIII i XIX wieku Wieś i dwór u kresu państwa polskiego i w latach zaboru austriackiego*
}

\author{
An Outline of the Agricultural Relations of the Lublin Region at the \\ Turn of the 18th and 19th Centuries. Village and Manor at the End \\ of the Polish State and in the Years of the Austrian Partition
}

\section{Wprowadzenie}

Problematyka związana z kondycją rolnictwa na Lubelszczyźnie u kresu państwa polskiego i w latach zaboru austriackiego znajduje się na uboczu zainteresowań naukowych historyków. Podobnie zresztą badacze podchodzą do charakterystyki (nie tylko ówczesnych) stosunków gospodarczych Lubelszczyzny - pozostają one w głębokim cieniu i ustępują pola innym zagadnieniom.

Wśród nie tak znów licznej reprezentacji opracowań, które na trwałe zapisały się w literaturze przedmiotu, wiodącą rolę odgrywają nadal te napisane w Xx wieku. Nie miejsce tu na szczegółowe analizowanie dorobku lubelskiej historiografii (zainteresowanych odsyłam do bibliografii załącznikowej), warto natomiast przywołać fundamentalne dzieło Tadeusza Mencla poświęcone dziejom Galicji Zachodniej w latach 1795-1809 ${ }^{1}$ oraz kilka prac opublikowanych w monografiach (syntezach) zbiorowych przez Józefa Mazurkiewicza i Wiesława Śladkowskiego². Wiele cennych informacji zawarli też w swoich książkach i artykułach

* Z dedykacją dla Pana Profesora Jarosława Kity

I T. Mencel, Galicja Zachodnia I795-I809. Studium z dziejów ziem polskich zaboru austriackiego po III rozbiorze, Lublin 1976.

2 J. Mazurkiewicz, $W$ czasach stanistawowskich, [w:] Dzieje Lubelszczyzny, t. I, red. T. Mencel, Warszawa 1974; W.Śladkowski, Podzaborem austriackim, w Księstwie Warszawskim i Królestwie Polskim, [w:] tamże. 
Julian Bartyś, Henryk Grossman, Kazimierz Krzos czy Halina Matławska ${ }^{3}$. Z kolei niezbędne konteksty dotyczące ówczesnych podziałów administracyjnych Lubelszczyzny i ustroju władz doskonale zarysowali Władysław Ćwik i Jerzy Reder ${ }^{4}$.

$\mathrm{Z}$ nowszej literatury na wymienienie zasługuje na pewno obszerna biografia Stanisława Kostki Zamoyskiego pióra Konrada Ajewskiegos. W ciekawy i zajmujący sposób o nowoczesnych metodach gospodarowania w dobrach Ordynacji Zamojskiej pisał też kilka lat wcześniej Jacek Feduszka ${ }^{6}$, zaś Krzysztof Ślusarek poświęcił swe doskonałe studium blaskom i cieniom reform agrarnych na ziemiach zaboru austriackiego ${ }^{7}$. Problematyka relacji wieś - dwóri stosunków gospodarczych w XIX stuleciu była również bliska autorowi niniejszej publikacji, który swoje rozważania zawarł w książce dotyczącej dóbr ziemskich w Snopkowie koło Lublina ${ }^{8}$.

Mając na względzie powyższe uwagi, artykuł stanowi sumaryczny i syntetyczny obraz realiów gospodarki wiejskiej międzyrzecza Wisły i Bugu na przełomie XVIII i XIXw. Tekst, zamknięty klamrą Wprowadzenia i Zakończenia, systematyzuje wiedzę na temat gospodarki Lubelszczyzny (przede wszystkim w dobie zaboru austriackiego), przybliża stan ówczesnej agrotechniki oraz opisuje mechanizmy tworzenia tutejszej kultury agrarnej. W swej skromnej postaci może on również stanowić przyczynek do szerszych badań komparatystycznych obejmujących nie tylko obie Galicje, ale też ówczesne stosunki wiejskie postrzegane w szerszym kontekście - ziem polskich pod trzema zaborami.

3 J. Bartyś, Hodowla owiec rasowych w dobrach Ordynacji Zamojskiej, „Studia z Dziejów Gospodarstwa Wiejskiego", t. II, red. J. Leskiewiczowa, Wrocław 1959; tenże, Początki mechanizacji rolnictwa polskiego, Wrocław-Warszawa-Kraków 1966; H. Grossman, Struktura spoteczna i gospodarcza Księstwa Warszawskiego na podstawie spisów I808-I8Io roku, „Kwartalnik Statystyczny”, t. II, Warszawa I926; K. Krzos, Z księciem Józefem w Galicji w I8og roku. Rząd Centralny Obojga Galicji, Warszawa 1967; H. Matławska, Zwierzyniec, Zwierzyniec i991.

4 W. Ćwik, J. Reder, Lubelszczyzna. Dzieje rozwoju terytorialnego, podziatów administracyjnych i ustroju wtadz, Lublin 1977.

5 K. Ajewski, Stanistawa Kostki Zamoyskiego życie i dziatalność 1775-1856, Warszawa 2010.

6 J. Feduszka, Nowoczesne metody gospodarowania w dobrach Ordynacji Zamojskiej w początkach XIX wieku - prekursorzy i propagatorzy, „Roczniki Naukowe Stowarzyszenia Ekonomistów Rolnictwa i Agrobiznesu" 2005, t. VII, z. 7.

7 K. Ślusarek, Blaski i cenie reform agrarnych w XIX-wiecznej Galicji, [w:] Wolni i uwtaszczeni. Chtopi a przemiany spoteczno-gospodarcze i polityczne w Europie Wschodniej w XIX i na początku XX wieku, red. D. Michaluk, Ciechanowiec 2017.

8 A. Przegaliński, Dwór ziemiański na Lubelszczyźnie wepoce przemian gospodarczych ispotecznych. Dzieje dóbr Snopków w XIX i w I potowie XX wieku, Lublin 2016. 
Ostatnie lata chylącego się pod obcą przemocą ku upadkowi państwa polskiego obfitowały w dramatyczne wydarzenia o charakterze politycznym, militarnym i w konsekwencji także gospodarczym. Agonia Rzeczypospolitej, poprzedzona wojną rosyjsko-polską w obronie konstytucji majowej, a później rządami Targowicy, zyskała swój heroiczny epilog w czasie powstania kościuszkowskiego?.

W trakcie insurekcji ziemie polskie uległy ogromnym zniszczeniom. Wojska rosyjskie, a potem także pruskie, które Is VI 1794 r. zajęły Kraków, zaś w lipcu i sierpniu zamknęły kordon wokół oblężonej Warszawy, paliły wsie, rabowały bydło, szlacheckie spichlerze i chłopskie stodoły, pustosząc przy tym pola uprawne. Późniejsza okupacja wojsk austriackich, rosyjskich i pruskich zapisała się w historii nie tylko haniebną grabieżą skarbów kultury i sztuki, ale też wzmożonymi kontrybucjami zbóż, mięsa i furażu oraz bezwzględną polityką podatkową. Klęskom wojennym towarzyszył narastający kryzys gospodarczy znaczony wzrostem cen zboża oraz powtarzającymi się w latach $1794-1795$ epidemiami. Te ostatnie spowodowane były głodem, który dał o sobie znać szczególnie w nieurodzajnym $1795 \mathrm{r}$., chłodem i przede wszystkim zarazą przywleczoną przez najezdne wojska ${ }^{\mathrm{I}}$. W nader smutnych, dramatycznych wręcz słowach opisywał położenie wsi Stanisław August w liście do carycy Katarzyny II datowanym 2I XII I794 r:
Zaburzenia wojskowe [pisał] uniemożliwily dokonanie zasiewów w znacznej części kraju. Uniemożliwiono orkę wszędzie tam, gdzie zabrano ludziom bydło. Tysiące wieśniaków, których stodoły stanęły pustką, których chaty uległy spaleniu lub spustoszeniu, zbiegło do innych krajów. Wielu właścicieli ziemskich musiało uczynić to samo i z tych samych powodów. Polska zaczyna się upodabniać do pustyni ${ }^{\mathrm{II}}$.

A działo się to przecież w okresie, kiedy państwo podjęło dzieło reform, dzięki którym odzyskiwało siły i możliwości samodzielnego decydowania o własnym losie. Sanacja ustroju i reforma prawa, wzmocnienie skarbu, rozwój handlu, rzemiosła i manufaktur (królewskich, szlacheckich i mieszczańskich), rozbudowa infrastruktury komunikacyjnej (roztoczono wszak

9 T. Prażmowska, Dzieje trzech rozbiorów Polski oraz ruchu narodowego w XIX w. (poprzedzone zarysem panowania domu saskiego), Warszawa 1910, s. 175-176; W. Smoleński, Konfederacja targowicka, Kraków 1903, s. 210-216; W.A. Serczyk, Katarzyna II, Wrocław 2004, s. 300; A. Zahorski, Powstanie kościuszkowskie 1794, [w:] S. Kieniewicz, A. Zahorski, W. Zajewski, Trzy powstania narodowe: kościuszkowskie, listopadowe, styczniowe, Warszawa 2000 , s. 19.

Io T. Mencel, dz. cyt., s. I89-I90; W. Czapliński, Zarys dziejów Polskido roku I864, Kraków 1985, s. 394.

II Cyt. za: S. Grodziski, E. Kozłowski, Polska zniewolona 1795-1806, Warszawa 1987, s. 3. 
opiekę nad drogami publicznymi i przystąpiono do budowy kanałów łączących ze sobą poszczególne rzeki), wreszcie wieńczące dzieło uchwalenie Konstytucji 3 maja - wszystko to świadczyło o przełamaniu stagnacji epoki saskiej i stanowiło budzący nadzieję prognostyk na odnowę życia politycznego i gospodarczego. Mimo to Rzeczpospolita schodziła do grobu jako organizm społecznie i gospodarczo zacofany. Podjęte w drugiej połowie XVIII stulecia reformy były zbyt późne i zbyt nikłe, co wobec dominacji społecznej i gospodarczej szlachty oraz słabości miast, wpływało spowalniająco na ogół przeobrażeń ${ }^{12}$.

Dla województwa lubelskiego nowe porządki pod hegemonią obcej władzy zaczęły się latem 1794 r. W czerwcu, po przegranej przez gen. Józefa Zajączka bitwie pod Chełmem (8 vi I794) i zajęciu Lubelszczyzny przez wojska rosyjskie, korpus gen. Otto Wilhelma von Derfeldena zniszczył kwitnącą polską kulturą, nauką i sztuką rezydencję książąt Czartoryskich w Puławach. Znacząco ucierpiała też Końskowola, która w XVIII stuleciu stanowiła wyróżniający się ośrodek handlu i rzemiosła. Miasto, poddane przez Rosjan bezwzględnej grabieży i dewastacji, po wkroczeniu Austriaków stało się widownią brutalnej wręcz okupacji wojskowej. Podobny los stał się udziałem Kurowa Ignacego Potockiego i Kocka, przebudowanego uprzednio przez księżnę Annę Jabłonowską. Krasnystaw, wedle Antoniego Baldacciego, jeszcze w 1799 r. przypominał antyczną Akwileję zburzoną przez Attylę w 452 r. $^{13}$

Do Lublina awangarda Derfeldena wkroczyła I3 VI 1794 r. Dzień później płk Roman Karłowicz Anrep, w imieniu rosyjskiego generała, nałożył na miasto kontrybucję w wysokości roo tys. złp, obniżoną następnie do 30 tys. złp. Pieniądze wpłacili ryczałtem zamożni kupcy ewangeliccy: Beniamin Finke, Szwajcar rodem z Gryzonii i Jan Weber. Poza tym z kasy miejskiej,

I2 L. Janowicz, Zarys rozwoju przemystu w Królestwie Polskim, Warszawa 1907, s. 8-ı; B. Leśnodorski, Historia i wspótczesność, Warszawa 1967, s. III, I26-127, 135; W. Rusiński, Rozwój gospodarczy ziem polskich w zarysie, Warszawa 1963, s. 145-149, 161-166; T. Korzon, Odrodzenie w upadku. Wybór pism historycznych, oprac. M.H. Serejski, A.F. Grabski, Warszawa 1975, s. 214-223; R. Orłowski, Problemy spoteczno-gospodarcze Lubelszczyzny XVII $i$ XVIII stulecia, „Annales Universitatis Mariae Curie-Skłodowska”, Sectio F, vol. 32, 1977, s. 84-86; J. Bardach, B. Leśnodorski, M. Pietrzak, Historia ustroju i prawa polskiego, wyd. piąte, Warszawa 2005, s. 289-295.

I3 K. Czernicki, Chetm przesztość i pamiątki, Chełm 1936, s. I6; T. Mencel, dz. cyt., s. 136-137, I89;

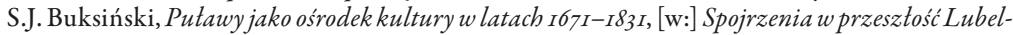
szczyzny, red. K. Myśliński i A.A. Witusik, Lublin 1974, s. 104; S. Herbst, Z dziejów wojskowych powstania kościuszkowskiego I794 roku, Warszawa 1983, s. 186-191, 264-265; R. Szczygieł, Od lokacji do upadku szlacheckiej Rzeczypospolitej, [w:] Dzieje Końskowoli, red. R. Szczygieł, Lublin 1988, s. 59-60; S. Wiśniewski, Pod rządami zaborców I795-I9I8, [w:] tamże, s. 6I; B. Szyndler, Powstanie kościuszkowskie 1794, Warszawa 1994, s. 207; K.A. Boreczek, Kurów. Od początku XVIII do potowy XX wieku. Część pierwsza I700-I9I8, Kurów 1996, s. 57-58; H. Mierzwiński, Księżna Anna Paulina z Sapiehów Jabtonowska (I728-180o), „Szkice Podlaskie” 1999, t. VII, s. 217; B. Banaś, Kurów jako ośrodek administracji. Od lokacji do 1939 roku, Kurów 2011, s. 30-31. 
na utrzymanie stacjonującego garnizonu i jego dowódcy Zubowa, wydatkowano 242 złp. Po ustąpieniu Rosjan, z początkiem lipca przybyli do miasta Austriacy, którzy w tym samym czasie zajęli Sandomierz. Wprawdzie w połowie miesiąca opuścili oni Lublin, niemniej już w sierpniu ponownie objęli województwo lubelskie i ziemię chełmską (kordon ciągnął się od Kazimierza nad Wisłą, przez Lublin, Łęczną i Chełm do Bugu), zabezpieczając w ten sposób własne interesy w przededniu kolejnego rozbioru Rzeczypospolitej. Lublin stał się wówczas siedzibą dowódcy wojsk cesarskich gen. Józefa von Harnoncourta. We wrześniu, wraz ze zwinięciem przez Prusaków oblężenia Warszawy, wojska okupacyjne usunęły się z Lublina. Miesiąc później, po klęsce maciejowickiej (ı października), która przyspieszyła upadek powstania kościuszkowskiego, Austriacy zajęli miasto na stałe, podobnie jak i tereny województwa lubelskiego i podlaskiego sięgającego po Łuków i Radzyń. W taki sposób dla międzyrzecza Wisły i Bugu zaczynała się nowa epoka, kiedy to dzieje Lubelszczyzny pisane były już pod zaborem ${ }^{4}$.

Po kilkumiesięcznych przetargach, w oparciu o podpisany 24 X $1795 \mathrm{r}$. akt trzeciego rozbioru (potwierdzony 26 I 1797 r. petersburską konwencją delimitacyjną) oraz na mocy patentu cesarza Franciszka II z 2 I III 1796 r., Lubelszczyzna, jako część tak zwanej Galicji Zachodniej (Nowej), została włączona do monarchii austriackiej. Stolicą nowego kraju koronnego obrano Kraków, gdzie ulokowano siedzibę Gubernium Krajowego oraz Dowództwo Generalne dla Galicji Zachodniej. Komisarzem urządzającym nowej prowincji, podzielonej na dwanaście cyrkułów, został baron Jan Wacław Margelik, zniemczony Czech, dotychczasowy wiceprezydent Gubernium Czeskiego, gorliwy realizator germanizacyjnej polityki Wiednia. Ziemie Lubelszczyzny (wraz z Podlasiem) wchodziły wówczas w skład sześciu cyrkułów (obwodów): lubelskiego, józefowskiego i chełmskiego, zaś na Podlasiu, wraz z częścią ziemi łukowskiej i Mazowsza: bialskiego, łukowskiego i siedleckiego. Poza granicami Galicji Zachodniej pozostawał utworzony w I783 r. cyrkuł zamojski, stanowiący, wraz ze stołecznym Zamościem, składową pozyskanego przez Wiedeń w I772 r. terytorium nazwanego Królestwem Galicji i Lodomerii lub Galicją Wschodnią (Starą). Po kilku latach, wraz z odwołaniem Margelika (I799), który walczył z nasilającą się

I4 K. Koźmian, Pamiętniki, t. I, oprac. J. Willaume i in., Wrocław-Warszawa-Kraków-Gdańsk I972, s. 266-268; J. Mazurkiewicz, Lublin w okresie reform (I764-I795), [w:] Dzieje Lublina. Próba syntezy, t. I, red. J. Dobrzański, J. Kłoczowski i J. Mazurkiewicz, Lublin 1965, s. 184; T. Mencel, Poczatki organizacji Galicji Zachodniej w latach $1795-1796$, ,Kwartalnik Historyczny” 1970, nr 2, s. 309; B. Szyndler, dz. cyt., s. 207; W. Śladkowski, dz. cyt., s. 485; tenże, W epoce zaborów, [w:] Lublin. Dzieje miasta, t. II: XIX i XX wiek, Lublin 2000, s. II-I2; H. Gmiterek, Lublin w wiekach XVII i XVIII, [w:] R. Szczygiet, H. Gmiterek, P. Dymel, Lublin. Dzieje miasta, t. I: Od VI do końca XVIII wieku, Lublin 2008, s. I58-I59. 
chorobą umysłową, jego obowiązki przejął hr. Jan von Trautmannsdorf. W lutym I80I r. uzyskał on tytuł gubernatora Galicji Zachodniej. Wkrótce potem ziemie te straciły odrębność administracyjną. W maju I $803 \mathrm{r}$. Trautmannsdorf ustąpił ze stanowiska. Zastąpił go, jako pełniący obowiązki gubernatora, Antoni Baum von Apfelhofen. Od listopada I 803 r. prowincja, zgodnie z polityką scalania tych terenów z Galicją Wschodnią, podlegała bezpośredniemu zarządowi Gubernium Krajowego we Lwowie ${ }^{15}$.

W następstwie przekształceń administracyjnych związanych z nową arondyzacją, czyli podziałem administracyjnym Galicji Zachodniej, ziemie Lubelszczyzny wraz z Podlasiem począwszy od I V I804 r. znalazły się w trzech cyrkułach (obwodach): lubelskim, który wchłonął cyrkuł józefowski, włodawskim z siedzibą w Białej (obejmował on także dotychczasowy cyrkuł chełmski) i siedleckim z centrum w Siedlcach. Latem I805 r. odwołano Dowódcę Generalnego Zachodniej Galicji, feldmarszałka Wenzela Kaunitza, co ostatecznie zakończyło proces likwidacji Gubernium Krajowego z siedzibą w Krakowie ${ }^{16}$.

Wchłonięty przez Austrię obszar Lubelszczyzny, sięgający od przedbużańskiej części ziemi chełmskiej aż po Podlasie wraz z ziemią łukowską, obejmował, wedle danych z 1797 r., około 26 tys. km² i liczył 612926 mieszkańców. Stanowiło to około połowy ogółu ludności Galicji Zachodniej. Biorąc z kolei pod uwagę nieco późniejsze dane pochodzące ze spisu przeprowadzonego w 1799 roku i odnosząc je do ziem, których centrum stanowiła Wyżyna Lubelska (a więc z pominięciem nizinnych terenów Podlasia i skrawka Mazowsza z Liwem, jako części cyrkułu siedleckiego), liczba mieszkańców cyrkułów lubelskiego, józefowskiego i chełmskiego wynosiła 287212 osób. Wśród nich dominowała ludność chrześcijańska (255870 osób) złożona w przeważającej części z Polaków. Drugą w kolejności nację stanowili Żydzi - mieszkańcy wsi i miasteczek liczący 3I 342 osób $^{17}$. Cztery lata

I5 H. Łopaciński, Podziaty administracyjne teraźniejszej guberni lubelskiej w różnych czasach, Pamiętnik Lubelski. Kalendarz Ilustrowany na rok 1904, Lublin 1904, s. 23; T. Mencel, Galicja..., s. 37, 39, 46, 49, 62, 306-307; tenże, Początki..., s. 321,323-324, 330-331; Geografia albo doktadne opisanie Królestw Galicji i Lodomerii, Lwów 1858, s. 44-51; M. Baczkowski, Czy Kraków mógt zostaćstolica Galicji na początku XIX wieku?, „Zeszyty Naukowe Uniwersytetu Jagiellońskiego” Prace Historyczne, 2009, z. 136, s. 49-50; W. Ćwik, J. Reder, dz. cyt., s. 64-66; I. Ihnatowicz, A. Biernat, Vademecum do badań nad historia XIX $i$ XX wieku, Warszawa 2003, s. 388 ; W. Śladkowski, Podzaborem..., s. 485; tenże, Wepoce..., s. II-I2; Z. Szymański, Gospodarka Lubelszczyzny w czasach stanistawowskich, „Zeszyty Naukowe wSEI”, Seria E, 2014 , z. 9, s. I 44.

I6 T. Mencel, Galicja..., s. 307, 310-3II; W. Ćwik, J. Reder, dz. cyt., s. 64-66; S. Grodziski, E. Kozłowski, dz. cyt., s. 3, 8; W. Śladkowski, Pod zaborem..., s. 485, 490-49I; Z. Szymański, dz. cyt., s. I44; M. Baczkowski, dz. cyt., s. 49-50.

17 T. Mencel, Galicja..., s. 69; W. Śladkowski, Pod zaborem..., s. 490, 492. Dla porównania: wedle spisu ludności diecezji krakowskiej przeprowadzonego w 1787 r., w województwie lubelskim (obejmującym ziemię lubelską, łukowską i powiat urzędowski) mieszkało 223315 osób, 
później na tym samym terenie mieszkało 293378 osób - 264433 chrześcijan i 28945 wyznawców religii mojżeszowej. W cyrkule zamojskim, liczącym w I803 r. I86 o80 osób, odsetek ludności żydowskiej wynosił 6,5\% ${ }^{18}$.

Przypadłe Habsburgom ziemie Lubelszczyzny charakteryzowały się zróżnicowanym krajobrazem naturalnym. Pod względem warunków glebowych do żyźniejszych należały obszary cyrkułu lubelskiego i józefowskiego w okolicach Bochotnicy, Końskowoli, Puław, Kurowa i Urzędowa oraz częściowo tereny cyrkułu chełmskiego, ze szczególnym uwzględnieniem sąsiedztwa Chełma, Krasnegostawu i okolic. Przeważały tam tłuste czarnoziemy na lessach, margle, glinki i rędziny. W rejonie Puchaczowa, Biłgoraja, Janowa i Kraśnika gleby były już uboższe, podobnie jak w regionie siedlecko-włodawskim, gdzie dominowały bielice, szczerki i piaski. Na wschodzie cyrkułu rozciągały się jeziora i bagna. Najbogatszy w urodzajne ziemie był cyrkuł zamojski, a zwłaszcza będący jego częścią północny obszar staropolskiego województwa bełskiego z Horodłem, Hrubieszowem i Tomaszowem ${ }^{19}$.

Następstwa rozbioru Rzeczypospolitej były dla Lubelszczyzny, tak jak i dla innych ziem polskich, czasem niestabilności politycznej i gospodarczej. Konsekwencje zmian geopolitycznych i prawno-ustrojowych związane z rozczłonkowaniem zrośniętego od wieków organizmu oraz brutalne wtłoczenie społeczeństwa w granice trzech zaborów i odarcie go z dawnych uprawnień i przywilejów stały się pobudką narastającego kryzysu, który uderzył we wszystkie warstwy społeczne. Wśród wielu następstw tego przesilenia na plan pierwszy wybijał się na pewno upadek ustabilizowanych od wielu dziesięcioleci rynków: wewnętrznego i zewnętrznego. Załamanie wymiany handlowej opartej o oś Wisły, jej dopływy i stałe szlaki transportowe, wreszcie utrata Gdańska, najruchliwszego podówczas portu nad Bałtykiem, zachwiały pozycję dworu jako producenta i eksportera zboża. Załamaniu ulegały także podstawy kształtującego się układu kapitalistycznego oraz zależności rynkowych opartych o większe centra wymiany handlowej. Przepływ usług, towarów i kapitałów zamknęły nowe, pilnie strzeżone granice, na których pobierano opłaty celne w wysokości dotychczas niespotykanej. Tysiące ludzi utraciło podstawy dotychczasowej egzystencji lub gwałtownie

w tym - 198734 katolików (89\%), 24220 Żydów (I0,84\%) i 36I dysydentów-różnowierców (o,16\%). Zob.: Spis ludności diecezji krakowskiej z r. 1787, wyd. J. Kleczyński, „Collectanea ex Archivo Collegii Historici”, t. viI, Kraków 1894, s. 281, 304.

I8 T. Mencel, Galicja..., s. 70; B. Kumor, Spisy ludności Galicji z lat I800-I808, „Przeszłość Demograficzna Polski” 1972, t. v, s. 73.

I9 H. Wiercieński, Opis statystyczny guberni lubelskiej, Warszawa 1901, s. 228-229; T. Mencel, Galicja..., s. 70, 205; W. Śladkowski, Pod zaborem..., s. 494; tenże, Po utracie niepodlegtości I795-I83I, [w:] Z przesztości dalekiej i bliskiej. Szkice z dziejów Lubelszczyzny, red. A. Koprukowniak i W. Śladkowski, Lublin I980, s. 160-161. 
zubożało. Szerzyła się drożyzna i bieda w najdrastyczniejszych niekiedy formach. Ogół mieszkańców paraliżowała obca mowa w urzędach, sądach i szkole, nieznane wcześniej prawa i upokarzająca buta nowych władz ${ }^{20}$.

Polityka dworów zaborczych wobec zagarniętych ziem polskich, opresyjna i reakcyjna, nie niosła też pozytywów w dziedzinie rozwoju gospodarczego nowo nabytych terytoriów. Dla Austrii, która, jak pisał Szymon Askenazy, czuła się - zwłaszcza w Galicji Zachodniej - raczej tymczasowym posiadaczem, niż właścicielem wieczystym i uważana była za „donatariusza pobocznego", oznaczało to wzmożoną działalność eksploatacyjną. Habsburgowie, traktujący ziemie Galicji Zachodniej jako przedpole ewentualnego konfliktu z Prusami lub Rosją, nie nakreślili też żadnych (poza doraźnymi) planów rozwoju gospodarczego i ekonomicznego zdobytych w trzecim rozbiorze terenó $w^{21}$. Polityka ta zmierzała przede wszystkim do ściągnięcia jak najwyższej daniny podatkowej i równie licznego rekruta - w latach 1796-I809 z obszaru Galicji Nowej wcielono do wojska co najmniej 80 tys. poborowych. Dla usprawnienia drenażu fiskalnego w każdym z cyrkułów zorganizowano jedną lub dwie kasy, które znajdowały się w większych miastach. Zgodnie z dyrektywami Franciszka II, który okazał się pojętnym kontynuatorem polityki Marii Teresy i Józefa II, wprowadzono dokuczliwy system rządów centralistycznych, policyjnych i biurokratycznych. Miało to sprzyjać unifikacji i germanizacji poszczególnych prowincji. Językiem urzędowym został niemiecki, którego znajomość, podobnie jak austriackich norm prawnych, była znikoma - nawet wśród elity szlacheckiej. Administracyjne godności i synekury powierzano w większości Niemcom oraz zniemczonym Czechom i Węgrom - nierzadko wrogo usposobionym wobec miejscowej ludności, ale też, siłą rzeczy, nieorientującym się w lokalnych problemach, bolączkach i potrzebach ${ }^{22}$. Nowe urządzenia prawne, różne dyrektywy i patenty spadały przy tym na Galicję, zwłaszcza w pierwszych latach, „jak grad” ${ }^{23}$. Kajetan Koźmian, wnikliwy obserwator życia politycznego zapamiętał, że „[patenty] acz po polsku tłumaczone,

20 F. Czermiński, O Towarzystwie Kredytowym Ziemskim w Królestwie Polskim, cz. I, ust. I, „Biblioteka Warszawska" I864, t. III, s. 71; I. Kostrowicka, Z. Landau, J. Tomaszewski, Historia gospodarcza Polski XIX i XX wieku, Warszawa I985, s. 43; M. Bogucka, Dzieje kultury polskiej do I9I8 roku, Wrocław-Warszawa-Kraków-Gdańsk-Łódź 1987, s. 258-259; A. Przegaliński, dz. cyt., s. 40-4I.

2I T. Mencel, Galicja..., s. 5; E.M. Ziółek, Wokresie rozbiorów i zaboru austriackiego, [w:] Lublin. 700 lat dziejów miasta, red. G. Figiel, R. Szczygieł, W. Śladkowski, Lublin 2017, s. I1 4.

22 K. Koźmian, dz. cyt., s. 275-276, 278; T. Prażmowska, dz. cyt., s. 218-219; K. Krzos, dz. cyt., s. 16, 19; R. Kołodziejczyk, R. Gradowski, Zarys dziejów kapitalizmu w Polsce, Warszawa 1974, s. 39-4I; T. Mencel, Galicja..., s. 420-428; tenże, Ciężary wojskowe Galicji Zachodniej w czasie wojen Austrii przeciw Francji w latach I796-I809, „Annales Universitatis Mariae Curie-Skłodowska”, Sectio F, vol. XXIX, 1974, s. 129-136; W. Śladkowski, Pod zaborem..., s. 485; W. Ćwik, J. Reder, dz. cyt., s. 66.

23 K. Koźmian, dz. cyt., s. 278. 
lecz i w oryginale i w thumaczeniu były tak ciemne, tak zawikłanie pisane, że ich nie tylko Polacy, lecz sami wykonawcy Niemcy zrozumieć nie mogli. Szły więc objaśnienia ciemniejsze od samych urządzeń" ${ }^{24}$.

Społeczeństwo polskie poddane ścisłej kontroli, „uwięzione” za kordonem granicznym, zgaszone upadkiem ojczyzny, biernie znosiło ucisk i trzymało się z dala od polityki. Wielu zamykało się w kręgu rodziny i przyjaciól. Rezygnowano z aktywności publicznej i nie nadskakiwano nowym władzom. Krzątano się natomiast wokół spraw prywatnych, skupiając się na codziennych troskach, radościach i kłopotach ${ }^{25}$.

Tak oto w ogólnych zarysach prezentowały się warunki życia politycznego, które tworzyły kontekst dla przeobrażeń gospodarczych pod zaborem austriackim.

\section{Wieś i dwór}

Międzyrzecze Wisły i Bugu stanowiło region, gdzie dominowała własność skupiona w rękach posiadaczy herbowych. Była to grupa społeczna o ogromnym zróżnicowaniu. Na samym szczycie znajdowała się nieliczna magnateria (arystokracja) - przez nowe władze uprzywilejowana i prawnie wyodrębniona ${ }^{26}$ oraz bogata szlachta - nierzadko dość dobrze wykształcona i wychowana, która utrzymywała dwory promieniujące na bliższą i dalszą okolicę kulturą i ożywionym życiem towarzyskim. Najważniejszą rolę odgrywały tu bezsprzecznie Puławy Adama Kazimierza i Izabeli Czartoryskich. Rezydencja, odbudowana ze zniszczeń wojennych, stała się na przełomie XVIII i XIX w. skarbnicą pamiątek narodowych oraz ośrodkiem wzniosłej myśli patriotycznej. Puławy, określane nobilitującym mianem „Aten polskich”, skupiały wokół księstwa wybitnych artystów, oświeceniowych poetów i pisarzy oraz światlejszych przedstawicieli arystokracji i szlachty. Otwarte i cenione przez współczesnych domy prowadzili też m.in. książęta Lubomirscy, a później Rzewuscy w Opolu Lubelskim, Kossowscy w Bełżycach, Prażmowscy w Gościeradowie oraz Suchodolscy w Wojcieszkowie. W cyrkule zamojskim wiodąca rola przypadła dobrom ordynackim, które za czasów dwóch kolejnych ordynatów: jedenastego - zmarłego przedwcześnie Aleksandra Augusta Zamoyskiego (1792-1800), a zwłaszcza

\footnotetext{
24 Tamże, s. 278-279.

25 W.Śladkowski, Pod zaborem..., s. 486; M. Bogucka, dz. cyt., s. 259.

26 Do stanu magnackiego należeli książęta, hrabiowie i baronowie oraz duchowieństwo wyższe łacińskie i greckie. Na ziemie Galicji Zachodniej rozciągnięto ustawodawstwo cesarzowej Marii Teresy, która potwierdziwszy polskie tytuły książęce, pozwoliła senatorom prosić o tytuł hrabiowski, a szlachcie-urzędnikom powiatowym o godność baronowską. Zob.: T. Prażmowska, dz. cyt., s. 217.
} 
dwunastego - Stanisława Kostki Zamoyskiego (I80I-I835), ożenionego zresztą z córką książąt Czartoryskich, Zofią, stały się centrum kultury i postępowej wiedzy agronomicznej opartej na wzorach angielskich, francuskich i niemieckich. Stanisław Kostka, wychowaniec Stanisława Staszica, zają się gorliwie doskonaleniem metod zarządzania oraz podnoszeniem poziomu gospodarstw rolnych i zakładów przemysłowych wchodzących w skład Ordynacji, co stanowiło pokłosie rozbudzonych w młodości zainteresowań i odbytych na przełomie wieków podróży ${ }^{27}$.

Idąca w dalszej kolejności szlachta średniozamożna była w zapatrywaniach społecznych konserwatywna, a na polu gospodarowania niewzruszenie tradycyjna. Poza dobrami rodowymi dzierżyła też często część lepszych starostw i wójtostw znajdujących się w dożywotnim lub czasowym posiadaniu. Niemałą „porcję” ogółu szlacheckiego stanowiła wreszcie uboga szlachta cząstkowa i zaściankowa, która sama doglądała rodzinnego siedliska i sukcesywnie ulegała prawnej deklasacji. Postępujący proces rozkładu i degradacji owej biedoty współgrał z polityką Wiednia. Władze austriackie dążyły bowiem do redukcji liczby szlachty drobnej, nakładając na ogół obowiązek udowodnienia szlachectwa - dla zaścianka kosztowny i trudny do spełnienia. Pomimo ubożenia, szlachta szaraczkowa trzymała jeszcze niekiedy drobne dzierżawy, rzadziej pośledniejsze wójtostwa i sołectwa. Nierzadko „opędzając głód” ${ }^{28}$, pozostawała na służbie u możniejszych dziedziców-protektorów. Zaścianek szlachecki, w większości niepiśmienny i niewiele różniący się od chłopów, odznaczał się przy tym wysokim poczuciem honoru, skłonnością do prawowania się z sąsiedztwem herbowym oraz pychą i lekceważeniem w stosunku do chłopów ${ }^{29}$.

27 H. Wiercieński, Pamiętniki, oprac. A. Zajączkowski, Lublin ı973, s. 4I; T. Mencel, Galicja..., s. 76-77; I. Ihnatowicz, Od rozbiorów do pierwszej wojny światowej, [w:] I. Ihnatowicz, A. Mączak, B. Zientara, J.Żarnowski, Spoteczeństwo polskie od X do XX wieku, wyd. trzecie, Warszawa 1996, s. 501; T. Opas, J. Reder, Betżyce. Studia i szkice z dziejów miasta, Lublin 1997, s. 50-55, 6I; M. Kozaczka, Poczet ordynatów Zamoyskich, Lublin 2004, s. 83-88; K. Ajewski, dz. cyt., s. 345-348; tenże, Ordynat Stanistaw Kostka Zamoyski oczami Anglika widziany, „Mazowieckie Studia Humanistyczne” 2005, nr I-2, s. 8-10; A. Aleksandrowicz, Putawy w latach I796-I83I, [w:] Z przesztości kulturalnej Lubelszczyzny, oprac. A. Aleksandrowicz, R. Gerlecka, W. Śladkowski, S. Tworek, Lublin 1978, s. 178-195; taż, Wartości chrześcijańskie w Putawach Czartoryskich (Naprzyktadzie twórczości księżnej Izabeli z Flemingów Czartoryskiej), [w:] Przestrzeń chrześcijańska w kulturzepolskiej. Polska i Putawy „na gtównym szlaku duchowych dziejów”, red. T. Giergiel, Puławy 2017, s. I38, I42-I43, I46-I47; Z. Gołębiowska, Mecenat kulturalny Izabeli i Adama Kazimierza Czartoryskich, [w:] Ziemiaństwo na Lubelszczyźnie II, red. R. Maliszewska, Kozłówka 2003, s. 3I-82; M. Demska-Trębacz, Muzyczny pejzaż Lubelszczyzny. Dworki i dwory, Lublin 2005, s. 36-73; A. Przegaliński, Gdy życiestato siępasją, a pasja byta muzyką. Studium zdziejów zatożenia patacowo-parkowego w Gościeradowie, „Teka Komisji Historycznej” 2010, t. VII, s. 5 I-56.

28 T. Korzon, Wewnętrzne dzieje Polski za Stanistawa Augusta (I764-I794), t. II, Warszawa I897, s. IOI.

29 H. Wiercieński, Pamiętniki..., s. 42; J. Willaume, $Z$ dziejów wsi lubelskiej przed uwtaszczeniem, „Annales Universitatis Mariae Curie-Skłodowska”, Sectio F, vol. x, I955, s. 85; T. Mencel, Galicja..., s. 76-77; I. Ihnatowicz, dz. cyt., s. 50I. 
Spośród przedstawicieli szlachty szaraczkowej i części szlachty bezrolnej rekrutowali się drobni urzędnicy, duchowni, nauczyciele i wojskowi, oficjaliści w większych dobrach (rządcy, ekonomowie, karbowi i leśniczy), a nawet lokaje czy stajenni w latyfundiach arystokratycznych. Katastrofy polityczne dotykające ziem polskimi u schyłku XVIII w. wstrząsnęły też niejedną fortuną magnacką i niejedną dobrze sytuowaną rodzinę szlachecką wyrzuciły na bruk miejski ${ }^{30}$.

W epokę zniewolenia zaborczego wkraczała Rzeczpospolita jako kraj w przeważającej części zagraryzowany, o niskim potencjale gospodarczym, co było szczególnie widoczne po prawej stronie Wisły. Zasadniczą gałąź gospodarki Lubelszczyzny, podobnie jak pozostałych ziem polskich, stanowiło rolnictwo. Wedle spisu ludności diecezji krakowskiej przeprowadzonego w 1787 r. - 175524 mieszkańców województwa lubelskiego, czyli $78,5 \%$, mieszkało na wsi, a 47 79I $(2 \mathrm{I}, 4 \%)$ w miastach. Faktycznie rolnictwo stwarzało podstawę bytu dla około $90 \%$ ludności - nie tylko we wsiach, ale i w niedorozwiniętych miastach i miasteczkach prywatnych o ustroju rolniczym. W rezultacie konsumpcja wytworów gospodarstwa wiejskiego przez ludność nierolniczą była niewielka. Ubogie drobnomieszczaństwo, podobnie jak chłopi, konsumowało tanie płody roślinne. Spożywano chleb razowy, kapustę, groch, rzepę i kluski z mąki razowej. $Z$ rzadka zadowalano się mięsem, jego pochodnymi i nabiałem $-\mathrm{z}$ wyjątkiem częściej pojawiającego się na stołach mleka ${ }^{31}$.

Produkcja roślinna miała tradycyjnie charakter zbożowy, co było pokłosiem staropolskiej polityki gospodarczej (prawda, że najbardziej korzystnej dla szlachty), która od stuleci wspierała rolnictwo jako dźwignię rozwoju ekonomicznego kraju. W folwarkach lubelskich dominowała uprawa żyta, owsa i jęczmienia (ponad $80 \%$ zasiewów), w mniejszym stopniu obsiewano pola pszenicą (Io\% zasiewów). Wobec zaniedbań w hodowli żywego inwentarza, niedostateczną rolę odgrywały rośliny paszowe (koniczyna i lucerna) - w gospodarstwach chłopskich, rozdrobnionych i biednych, prawie nieznane. Na przełomie stuleci plony uzyskiwane na tłustych, pszeniczno-żytnich glebach lessowych wynosiły od czterech do pięciu ziaren, na pozostałych, sapowatych i piaszczystych, obsiewanych zazwyczaj żytem, owsem i tatarką, kształtowały się na poziomie dwóch-trzech ziaren.

30 H. Wiercieński, Pamiętniki..., s. 41-42; T. Mencel, Galicja..., s. 77; J. Leskiewiczowa, Zamiast wstępu, [w:] Ziemiaństwo polskie 1795-1945, red. J. Leskiewiczowa, Warszawa 1985, s. 9.

3I Spis ludności diecezji..., s. 282; H. Grynwaser, Kwestia wtościańska i ruch wtościan w Królestwie Polskim w pierwszej potowie XIX wieku, Warszawa 1935, s. 20-2I; J. Mazurkiewicz, W czasach stanistawowskich..., s. 453; W. Pruski, Hodowla zwierząt gospodarskich w Królestwie Polskim w latach $1815-1918$, t. I, Warszawa 1967, s. 20; W. Śladkowski, Pod zaborem..., s. 494; B. Kumor, dz. cyt., tab. v, nlb. 
Podobne wartości otrzymywano w skali całej Galicji Zachodniej, gdzie plony zbóż były niskie i dawały przeciętnie trzy ziarna. Na tym tle na początku XIX w. wyróżniał się cyrkuł siedlecki - tam ogólny sprzęt czterech zbóż (pszenicy, żyta, jęczmienia i owsa) w I802 r. wyniósł 372703 korce, co było najwyższą wartością w Galicji Zachodniej. W cyrkule lubelskim zebrano wówczas 310533 korce, w cyrkule józefowskim - 292 798, a w cyrkule chełmskim - I84 307 korców32.

Pozostawiając jeszcze na chwilę na uboczu rozważania dotyczące stosunków rolniczych w Galicji w dobie zaboru austriackiego, godzi się przypomnieć, że Rzeczpospolita u kresu swych dni, pomimo pewnego postępu w rolnictwie w epoce stanisławowskiej, była krajem prymitywnej gospodarki folwarczno-pańszczyźnianej. Wzrastała wprawdzie rola czynszu w ekonomice rolnej, ale reformy czynszowe podjęte przez dziesiątego ordynata Andrzeja Zamojskiego (1777-1792) w kluczu janowskim, przez książąt Czartoryskich w kluczu końskowolskim, Puławach „zarobnych” i we Włostowicach oraz przez księżnę A. Jabłonowską w dobrach kockich i siemiatyckich (ta ostatnia rozluźniła zależność osobistą chłopów oraz poszerzyła ich prawo do ziemi i osady przy zachowaniu pomniejszonego i szczegółowo uregulowanego wymiaru pańszczyzny) nie spotkały się na Lubelszczyźnie z powszechniejszym odzewem. Były to zresztą przedsięwzięcia, które po pewnym czasie ulegały częściowej bądź pełnej likwidacji ${ }^{33}$.

W latach zaboru austriackiego stosunki społeczno-gospodarcze między wsią a dworem opierały się nadal na dominacji patriarchalnej dziedzica i poddaństwie chłopów. Realizowane w monarchii naddunajskiej w latach 1775-1789 reformy terezjańsko-józefińskie wiodły wprawdzie do dość gruntownej, jak na ówczesne czasy, przebudowy modelu gospodarki folwarczno-pańszczyźnianej i zależności między wsią a dworem ${ }^{34}$, niemniej po

32 T. Łepkowski, Polska - narodziny nowoczesnego narodu, Warszawa 1967, s. 19; K. Krzos, dz. cyt., s. 24; W. Śladkowski, Po utracie..., s. I6I; tenże, Pod zaborem..., s. 496; T. Mencel, Galicja Zachodnia..., s. 204-205.

33 J. Mazurkiewicz, $W$ czasach..., s. 445-446; H. Mierzwiński, dz. cyt., s. 212; tenże, Dziatalność opiekuńczo-wychowawcza księżnej Anny Pauliny z Sapiehów Jabtonowskiej na tle dziejów, „Szkice Podlaskie" 2002, t. X, s. 23-26; Z. Szymański, dz. cyt., s. 147-149; Z. Gołębiowska, Dwór a modernizacja wsi polskiej na przyktadzie ośrodka putawskiego Czartoryskich, [w:] Wieśa dwór na ziemiach polskich wXIX i XX wieku, red. W. Caban, M.B. Markowski, Kielce I999, s. 66-67; D. Rzepniewska, Problematyka ziemiańska w aktach hipoteki dóbr ziemskich, [w:] Ziemiaństwo polskie 1795-1945, red. J. Leskiewiczowa, Warszawa 1985, s. 190, 215-216.

34 W ramach reform podejmowanych przez Marię Teresę i Józefa II zniesiono poddaństwo osobiste chłopów (I782), ograniczono pańszczyznę do trzech dni w tygodniu (robotpatent z 1786 r.), zredukowano lub zniesiono niepłatne robocizny (gwałty, tłoki), dokonano podziału gruntów na dominialne (w rękach dziedzica) i rustykalne (w dziedzicznym użytkowaniu włościan), wprowadzono też pośrednictwo państwa w sporach między wsią a dworem (instytucje justycjariatu i mandatariatu). W I787 r. zakazano włączania gruntów chłopskich do dziedzin 
śmierci Józefa II (I790), w dobie tzw. dejózefinizacji za rządów Leopolda II (1790-1792) i Franciszka II (1792-I806) przeobrażenia te cofnięto i nigdy już do nich nie powrócono. Chłop galicyjski pozostał skrępowany poddaństwem, obarczony pańszczyzną i daremszczyznami (darmochami), zdany na samowolę sądowniczą pana patrymonialnego - na ziemiach trzeciego zaboru austriackiego nie ustanowiono bowiem instytucji justycjariatu. Formalnie obowiązująca swoboda opuszczenia wsi została przekreślona obowiązkiem wskazania zastępcy. Martwą literą pozostał przepis dotyczący zakazu samowolnej zamiany i włączania gruntów chłopskich do dziedzin dworskich, zaś ewentualną umowę konwersji pańszczyzny na czynsz obłożono licznymi warunkami, które z reguły uniemożliwiały zawarcie kontraktu. W takich realiach kiełkujący wówczas proces rozwarstwienia ludności chłopskiej na majętniejszych kmieci i półrolników, małorolnych chałupników i ogrodników oraz bezrolnych komorników, wyrobników, parobków i dziewki służebne nie wpływał na charakter gruntownych przeobrażeń dotykających chałupy przeciętnego włościanina ${ }^{35}$.

Pozarolnicze zajęcia i zarobki wsi, wobec ograniczeń wolności osobistej i rozlicznych zobowiązań wobec dworów, były dorywcze i sezonowe. Najczęściej najmowano się do wyrębu lasów, który wymagał ciężkiej roboty ręcznej i sprzężajnej. Takie prace prowadzono zwłaszcza wzdłuż spławnych rzek, tam też część zamożniejszych włościan trudniła się furmaństwem, przewożąc zboże, drzewo, kamienie i sól. Niektórzy (także w ramach powinności pańszczyźnianych) byli zatrudniani w nielicznych manufakturach. Jako robotnicy niewykwalifikowani zajmowali się m.in. wypalaniem węgla drzewnego, pakowaniem gotowych produktów, dostawami i transportem. Inni zbierali i tłukli kamienie niezbędne do budowy i konserwacji dróg. W wielu wsiach trudniono się także tkactwem, wyrabiając odzież samodziałową oraz półprodukty dla dworu. Sukiennictwo i płóciennictwo bujnie

dworskich. Ukoronowaniem tych przedsięwzięć doby oświeconego absolutyzmu była przygotowana przez Józefa II reforma urbarialna (1789). Przewidywała ona na terenie całego państwa powszechną zamianę pańszczyzny i danin na czynsze pieniężne obliczane na podstawie dochodu z gospodarstw chłopskich. Zasadą było zabezpieczenie włościanom $70 \%$ uzyskanego przychodu, pozostała część pieniędzy miała zaspakajać świadczenia na rzecz państwa, gminy, Kościoła i dziedzica. Szerzej zob.: A. Świętochowski, Historia chtopów polskich w zarysie, t. II: W Polscepodlegtej, Lwów-Poznań 1928, s. 5-13; R. Kołodziejczyk, R. Gradowski, dz. cyt., s. 39; S. Inglot, Historia spoteczno-gospodarcza chtopów polskich w zaborze austriackim, [w:] Historia chtopów polskich, t. II: Okres zaborów, red. S. Inglot, Warszawa 1972, s. 162-163; I. Kostrowicka, Z. Landau, J. Tomaszewski, dz. cyt., s. 47; K. Krzos, dz. cyt., s. 22-23; S. Grodziski, Habsburgowie, [w:] Dynastie Europy, red. A. Mączak, Wrocław-Warszawa-Kraków 1997, s. 125-126; A. Jezierski, C. Leszczyńska, Historia gospodarcza Polski, Warszawa 1998, s. ıоo; K. Ślusarek, dz. cyt., s. 364-366.

35 Z. Ludkiewicz, Polityka agrarna, wyd. czwarte, Poznań I921, s. ıı; W. Grabski, Historia wsi w Polsce, Warszawa 2004, s. 199; K. Krzos, dz. cyt., s. 23-24; K. Ślusarek, dz. cyt., s. 366-367. 
rozwijało się również w cyrkule zamojskim, gdzie produkcję chałupniczo-rękodzielniczą wspierał dwunasty ordynat oraz w dobrach hrubieszowskich wraz z sąsiednimi wioskami i przysiółkami. Tamże przedrozbiorowe tradycje kultywował S. Staszic, który w i8 o r r. nabył majętność na nazwisko Anny z Zamoyskich Sapieżyny ${ }^{36}$.

Ogólnie rzecz biorąc, wieś szlachecka tkwiła głęboko w prymitywizmie i zacofaniu technicznym, co było szczególnie widoczne na terenach obu Galicji. Wielu dziedziców, pomimo dokonywanych za czasów austriackich pomiarów, nie znało przybliżonej powierzchni posiadanych dóbr i opierało swą wiedzę na danych i określeniach wywiedzionych z rodzinnej tradycji, zwyczaju lub z lokalnego nazewnictwa. Takie dominia były zazwyczaj pobawione folwarków pomocniczych, które systematyzowały i porządkowały strukturę agrarną. Całość zabudowy, gruntów ornych oraz żywego i martwego inwentarza znajdowała się w sąsiedztwie dworu. Pozostałe ziemie, podobnie jak nieurządzone lasy, leżały odłogiem i ulegały postępującej degradacji ${ }^{37}$.

Charakterystycznym obrazkiem tutejszego rolnictwa był zespół majątkowy znajdujący się w szachownicy nie tylko z osadami chłopów, ale i sąsiednich dóbr szlacheckich. Chłopi siedzący na większych nadziałach ziemi i użytkujący załogę odbywali tradycyjną pańszczyznę sprzężajną nazywaną też ciągłą. Robocizna piesza obowiązywała na ogół małorolnych zagrodników oraz bezrolnych chałupników i komorników. Zobowiązania wsi obejmowały poza tym dodatkowe powinności, czyli wyżej wymienione daremszczyzny i najmy przymusowe oraz daniny w naturze - z reguły pod postacią wykastrowanych i specjalnie utuczonych kogutów (kapłonów), kur oraz motków z przędziwa lnianego lub konopnego. Chłopi płacili poza tym tzw. czynsz siedzialny, który stanowił opłatę pieniężną z części lub całości użytkowanych gruntów ${ }^{38}$.

Wiedza agrotechniczna chłopów, ale i większości szlachty była nader skromna i nie wykraczała poza stosowany powszechnie system trójpolowy z nieodłącznym ugorem. Płodozmian, ogólnie rzecz biorąc w pasie Europy środkowo-wschodniej, torował sobie drogę powoli i wprowadzano go na ogół eksperymentalnie. Narzędzia do uprawy ziemi były bardzo proste, sięgające

36 T. Korzon, dz. cyt., s. ıо ; H. Wiercieński, Opis statystyczny..., s. 409-41o; J. Bartyś, Sukiennictwo w ordynacji zamojskiej w I potowie XIX wieku, „Przegląd Historyczny” 1958, nr 3, s. 487; T. Mencel, Galicja..., s. 216; J. Duda, Towarzystwo Rolnicze Hrubieszowskie. Staszicowski model pomocy gospodarczej dla wsi, Lublin 1994, s. 22; K. Wróbel-Lipowa, Na przetomie epok. Hrubieszów w Galicji Wschodniej (I772-I809), [w:] Dzieje Hrubieszowa, t. I: Odpradziejów do I9I8 roku, red. R. Szczygieł, Hrubieszów 2006, s. I53-I54, I63.

37 A. Przegaliński, Dwór..., s. 37; K. Krzos, dz. cyt., s. 22-25; W. Pruski, dz. cyt., s. 33; D. Rzepniewska, dz. cyt., s. 190, 215-216.

38 T. Mencel, Wieśpańszczyźniana w Królestwie Polskim, Lublin 1988, s. 128-194; W. Śladkowski, Pod zaborem..., s. 48; J. Czubaty, Księstwo Warszawskie (I807-1815), Warszawa 2011, s. 314; A. Przegaliński, Dwór..., s. 53-54. 
swym rodowodem wcześniejszych okresów. Do prac polowych wykorzystywano zaprzężone w woły drewniane pługi, płużyce, sochy i radła. Brony wyplatano z chrustu. Prowadzona w taki sposób orka była niedokładna, płytka i nieefektywna. Podejmowane przez część światlejszych dworów nieśmiałe próby stosowania pewnych innowacji w dziedzinie uprawy i hodowli, które polegały na zastępowaniu w radłach i pługach części drewnianych żelaznymi, używaniu kos, rzadziej młynków do czyszczenia zboża i markerów do sadzenia kartofli, nieliczne wreszcie usiłowania intensyfikacji produkcji roślinnej związane z uprawą roślin pastewnych i motylkowych nie wpływały na ogólny stan rolnictwa. W większych majątkach istniały wprawdzie warsztaty dworskie, w których zatrudniano na stałe lub dorywczo rzemieślników wraz z czeladzią, ale ludzie ci zajmowali się na ogół wyrobem i reparacją tradycyjnych narzędzi rolniczych. Na zakup sprowadzonego z zagranicy pługa czy sieczkarni mógł sobie pozwolić jedynie człowiek majętny - były to bowiem urządzenia drogie, trudne w obsłudze i nieposiadające na ziemiach polskich żadnego zaplecza serwisowego. Na nieco szerszą skalę udoskonalenia te obserwowano w zaborze pruskim - w Poznańskiem i na Pomorzu oraz w okolicach Warszawy, a więc na terenach bardziej zurbanizowanych i gospodarczo lepiej stojących, gdzie czynszowanie chłopów, ściśle związane z intensyfikacją produkcji folwarcznej, prowadziło do systematu pracy najemnej"39.

Po prawej stronie Wisły działania zmierzające do upowszechniania zdobyczy nowoczesnej wiedzy agronomicznej były sporadyczne i w dłuższej perspektywie nieudane. Ożywcze prądy dobiegały przede wszystkim z terenu Zamojszczyzny. Prace inicjowane przez S.K. Zamoyskiego w porozumieniu z profesorami Liceum Zamojskiego (Wojciechem Gutkowskim, nauczycielem architektury i propagatorem nowoczesnego rolnictwa oraz Bazylim Kukolnikiem, entuzjastą fizjokratyzmu) nie znajdowały zrozumienia wśród szlachty i nie przenikały granic cyrkułu. W takich realiach zawiązane w i80 I r. Zamojskie Towarzystwo Ekonomiczne nie rozwinęło szerszej działalności, zaś założony dwa lata później „Dziennik Ekonomiczny Zamojski” o profilu rolniczo-techniczno-ekonomicznym, który docierał do Lwowa, Krakowa i Warszawy, przestał ukazywać się w połowie i804 r. Spaliła też na panewce próba zorganizowania towarzystwa rolniczego w Galicji Zachodniej - inspirowana przez „Dziennik”, a później rozważana przez wiedeńską Zjednoczoną Kancelarię ${ }^{\circ}$.

39 T. Łepkowski, dz. cyt., s. 21, 25; W. Rusiński, Zarys historii gospodarczejpowszechnej. Czasy nowożytne i najnowsze (I50o-1939), Warszawa I970, s. 196; W. Śladkowski, Pod zaborem..., s. 499; I. Kostrowicka, Z. Landau, J. Tomaszewski, dz. cyt., s. 28-29; J. Bartyś, Początki..., s. 42.

40 G. Czajka, Myśl ustrojowa ispoteczna Wojciecha Gutkowskiego, Kraków 2009, s. I0-1I, mps pracy magisterskiej. Dostępna w Internecie: http://www.knhd.law.uj.edu.pl/documents/3035628/6cdd2a32- 
O wiele dłuższy żywot i solidniejsze podstawy zyskała natomiast ordynacka wytwórczość maszyn i narzędzi rolniczych w Zwierzyńcu, który za czasów dwunastego ordynata stał się centrum zarządu i przemysłu tego latyfundium. Zakład zorganizowany w latach $\mathrm{I} 803-1805$ i nazywany mechaniką lub Fabryką Angielską (uruchomiono go bowiem „na wzór angielski”) stanowił pierwsze tego typu przedsięwzięcie na ziemiach polskich. Kierownikiem mechaniki został fachowiec, Szkot John Mac Donald, który współpracował ze specjalistami sprowadzonymi przez Ordynację z Anglii, Niemiec i Francji. Manufaktura została zrazu umieszczona w zabudowaniach ordynackich - tokarnia i stolarnia w opuszczonych stajniach, kuźnia w murowanej wozowni, gisernia, czyli odlewnia w dawnej kuchni dworskiej. Z czasem przeniesiono wytwórnię do obiektów własnych wzniesionych w miejscu stajen. Bolączką fabryki było wprawdzie peryferyjne położenie - odległe od centrów handlowych, przemysłowych i surowcowych oraz od głównych traktów komunikacyjnych i dróg bitych - niemniej w dziale zaopatrzenia problemy te nie mały zrazu istotniejszego znaczenia. Niezbędne do produkcji metale oraz niektóre detale i półfabrykaty zakupiono bowiem $\mathrm{w}$ wielkich ilościach $\mathrm{w}$ Londynie i zmagazynowano w składach fabrycznych. Mechanika korzystała z pracy ręcznej i polegała w znacznej mierze na potencjale chłopów zwierzynieckich. Zakład specjalizował się w produkcji młocarni, sieczkarni, siewników, młynków do zboża, krajarek do ziemniaków, ekstyrpatorów do karczowania korzeni, pługów i kultywatorów oraz urządzeń do gorzelni, olejarni, browarów i foluszy. U schyłku zaboru austriackiego pracowały w wytwórni dwadzieścia dwie osoby: dwóch mosiężników, trzech stelmachów, sześciu ślusarzy, trzech kowali, czterech stróżów i czterech parobków. Wyroby ze Zwierzyńca odznaczały się wysoką jakością wykonania i nie ustępowaty podobnym towarom importowanym z zachodu Europy. W epoce zaboru austriackiego mechanika zaspokajała przede wszystkim potrzeby dóbr ordynackich, a niewielkie nadwyżki produkcji przeznaczano na sprzedaż ${ }^{4 x}$.

$\mathrm{f}_{4} \mathrm{f}_{3-4}$ de8-9a36-3ar87of 2cce3; T. Mencel, Galicja..., s. 221-222; W. Śladkowski, Pod zaborem..., s. 499; tenże, W latach zaborów i nadziei wolności I795-I83I, [w:] Z przesztości kulturalnej..., s. I67; K. Ajewski, Stanistawa Kostki..., s. 345-348; J. Feduszka, dz. cyt., s. 63-65; A. Szyszka, B. Szyszka, Mecenat oświatowy Stanistawa Kostki Zamoyskiego, „Przegląd Historyczno-Oświatowy” 20ı。, R. LIII, z. 3-4, s. 19-20.

4I K. Ajewski, Stanistawa Kostki..., s. 386-387; H. Matławska, dz. cyt., s. 175-176; M. Kozaczka, dz. cyt., s. 88; J. Feduszka, dz. cyt., s. 67; J. Bartyś, Początki..., s. 48-49, 59, 62-63; W. Bondyra, Stownik historyczny miejscowości województwa zamojskiego, Lublin-Zamość 1993, s. I43; A. Kiper, Anglicy w Ordynacji Zamojskiej w XIX wieku, „Rocznik Kolbuszowski” 20I2, R. XII, s. 74-75; Z. Gołębiowska, Przybysze z Wysp Brytyjskich i ich potomkowie między Pilica a Bugiem w XVIII-XIX wieku, [w:] Ważna obecność. Przedstawiciele państw i narodów europejskich wśród mieszkańców międzyrzecza Bugu i Pilicy w XVIII-XIX wieku, red. A. Górak i K. Latawiec, Radzyń Podlaski-Radom 2006, s. I32-I33. 
Tymczasem przy niepodzielnie panującej pańszczyźnie, porównywalnie niższych cenach zboża, braku pieniędzy u chłopów (obciążonych zobowiązaniami podatkowymi wobec państwa i ciężarami dominialnymi wobec dworów), przy niemożności uzyskania przez szlachtę dogodnego kredytu obrotowo-inwestycyjnego, stagnacja lubelskiej wsi była powszechna. Położenie gospodarcze rolnictwa pogłębiały niedomagania demograficzne i rynkowe będące wypadkową małej ilości ludności miejskiej, która w niewielkim procencie pozostawała poza rolnictwem, braku dużych ośrodków handlowo-przemysłowych i niewielkiej konsumpcji wewnętrznej. Przy niskich cenach podstawowych płodów rolnych nie opłacało się zwiększać produkcyjności i konkurencyjności gospodarstw, nie przynosiło to bowiem dochodów. Nie warto więc było starć się o lepszy sprzężaj, narzędzia i maszyny rolnicze, nie niosło też profitów podnoszenie poziomu hodowli czy stanu zabudowy. „Najlepiej kalkulowało się [pisał Witold Pruski] zasiać i sprzątnąć najprymitywniejszym i najtańszym sposobem i trzymać się starego systemu trójpolowego, powiązanego z ustrojem pańszczyźnianym, nie wymagającym prawie żadnych nakładów" ${ }^{22}$.

Pomimo szeregu trudności będących konsekwencją upadku polskiej państwowości i prymitywnego gospodarowania, wbrew nasilającemu się uciskowi fiskalnemu i realnemu spadkowi dochodów, gospodarka folwarczno-pańszczyźniana przetrwała lata zaboru austriackiego w dość dobrym stanie. Właściciele ziemscy, odsunięci od życia politycznego i nieodczuwający na ogół brzemion represji, zamknęli się w kręgu spraw domowych i rolniczych. $\mathrm{Z}$ rzadka pojawiali się w mieście, cenili sobie natomiast uroki życia na prowincji. W gronie familii i znajomych, oddając się (tak jak wcześniej) zabawom i ucztom, zapomniano o różnych kłopotach i doskwierającej rzeczywistości. Szlachta pilnowała gospodarki folwarcznej, pokornie opłacała nowe podatki, a od groźnych następstw kryzysu wywołanego zagładą państwa broniła się po staremu - bezwzględnie egzekwując pańszczyznę ${ }^{43}$. „Wielu z nich [jak pisał Wiesław Śladkowski] zaokrągliło [też] swoje fortuny, nabywając po niskiej cenie pospiesznie sprzedawane przez rząd zaborczy dobra narodowe" 44 .

42 W. Pruski, dz. cyt..., s. 2 I.

43 Tak na ten temat pisał Leon Dembowski, który jako nastolatek bywał częstych gościem w Puławach książąt Czartoryskich: „Tymczasem fety, bale, zabawy, zjazdy szły torem zwykłym, a i my w nich pewien przyjmowaliśmy udział. Naprzód do jedzenia wszystkich specjałów, deserów i cukierków, następnie do powiększania liczby spektatorów w fetach i sztukach teatralnych, a wreszcie dawano nam role dzieci, o ile do widowiska należały. [...] Kiedy się dziś zastanawiam i rozważam, jaki był cel podobnego życia, jedną tylko znajduję odpowiedź - oto zapominano o wszystkim i myślano jedynie o tym, żeby się dobrze bawić, a większość towarzystwa zapominała o swoich interesach własnych i prawie na domowników puławskich się zamieniała”. L. Dembowski, Moje wspomnienia, t. I, Petersburg I898, s. 44-47. Zob. też: T. Korzon, Wewnętrzne..., s. IOI-IO2.

44 W. Śladkowski, Pod zaborem..., s. 504. 
Galicyjskiemu rolnictwu sprzyjała bowiem na przełomie wieków koniunktura na drzewo, a zwłaszcza na zboże, która nasiliła się wraz ze zniesieniem ograniczeń na spław pszenicy Wisłą, Sanem i Bugiem (1796) oraz obniżeniem ceł na zboże eksportowane przez Gdańsk do Anglii. Istotną rolę odegrał także nieurodzaj w Prusach, będący następstwem długotrwałej i ostrej zimy 1799/I800 r., a następnie suszy. Wobec utrzymania przez Prusy swobody handlu tranzytowego via Gdańsk, ceny zboża rosły, przedłużając okres prosperity do I804 r. W kolejnych latach przez ziemie galicyjskie dwukrotnie przechodziły wojska rosyjskie - jesienią I805 r. i na początku I806 r. Spowodowało to masowe dostawy żywności i niemal dwukrotny wzrost cen na pszenicę w Galicji, Czechach i na Morawach. Dla szlachty ten okres „pomyślności zbożowej” skutkował ożywieniem akcji zagospodarowywania leżących odłogiem gruntów i łąk, które z reguły przeznaczano pod uprawę niezbyt popularnej uprzednio pszenicy. Powodzenie w interesach łagodziło nieco frustrację wywołaną upadkiem państwa, ale i poczuciem winy powodowanym biernością polityczną szlacheckich posesjonatów ${ }^{45}$.

Ciekawie też rysowały się kwestie dotyczące gospodarki leśnej. Władze austriackie zezwoliły początkowo na eksport wszystkich gatunków drewna. Wkrótce jednak, na mocy zarządzenia z 3 VIII 1796 r., uprzywilejowano wywóz drzewa opałowego i budulcowego. Eksport do innych celów obwarowano koniecznością wykupienia paszportu i opłacenia taksy. W I800 r. wprowadzono niższe cło wywozowe na drzewo transportowane do spławu z dalszych okolic. Liberalizując politykę i rozluźniając nieco sztywny gorset zakazów, Austriacy uwolnili w istocie handel drewnem i jego wywóz. Takie postępowanie nie było, rzecz jasna, bezinteresowne - miało bowiem sprzyjać dopływowi gotówki niezbędnej do opłacenia podatków. Starano się przy tym kontrolować wysokość eksportu za pośrednictwem inspektoratów celnych, które sporządzały rejestry wywozowe. Po kilku latach, na mocy patentu cesarskiego z I3 VIII I807 r. wydano szczegółowe przepisy dotyczące gospodarki leśnej w lasach miejskich, szlacheckich i duchownych. Ich użytkowanie miało opierać się na pomiarach i podziale poszczególnych obszarów na wyręby (poręby) dostosowane do charakteru drzewostanu. Wyrąb całkowity uzależniono od obowiązku zasadzenia nowego lasu. Na gruntach piaszczystych dozwolono jedynie na przycięcia z pozostawieniem młodnika. Halizny, nazywane też goliznami, nakazywano zaorać, obsiać zbożem jarym, a następnie zasiać

45 R. Kołodziejczyk, R. Gradowski, dz. cyt., s. 4I; T. Mencel, Galicja..., s. 190-20I; J. Leskiewiczowa, dz. cyt., s. 20; J. Kaliński, Historia gospodarcza XIX $i$ XX w., wyd. drugie, Warszawa 2008 , s. 43-44; A. Przegaliński, Dwór..., s. 42; T. Kizwalter, I795-I83I, [w:] Historia Polski. Polska $1586-1831$, t. 6, Warszawa 2007 , s. 497. 
nasionami drzew. Ustalono też okresy cięcia lasów (od listopada do końca lutego) i graniczny termin wywozu (do maja $)^{46}$.

Po prawej stronie Wisły planowy charakter korzystania z lasów, który mógł stanowić wzór dla innych posesjonatów, przybrała gospodarka leśna w dobrach Ordynacji Zamojskiej. Począwszy od jesieni I804 r., wraz z zaprowadzeniem Dyrekcji Administracji Leśnej, której kierownictwo powierzono sprowadzonemu z Czech specjaliście, Karolowi Wilhelmowi Schwobdzie (Szwobdzie), zajęto się ich porządkowaniem i usprawnianiem przemysłu drzewnego. Ten ostatni opierał się na produkcji tartacznej, wyrobie gontów oraz pracy smolarni, w których, poza smołą, wytwarzano terpentynę, oleje i węgiel drzewny niezbędny do produkcji potażu. Lasy ordynackie pod względem administracyjnym podzielono na 2I jednostek zwanych ujazdami, a te ostatnie na I54 dzielnice. Sukcesywnie porządkowano sposoby pozyskiwania drewna i odnawiania drzewostanu, wyznaczono poszczególne koleje wyrębów, prowadzenia pomiarów i sporządzania map. Rozpoczęto też intensywne obsiewy porębów-halizn, wypalenisk i pustek, szczegółowo określono obowiązki służby leśnej, wytyczono również drogi dojazdowe prowadzące w ordynackie knieje ${ }^{47}$.

Za czasów panowania austriackiego dwory, w obawie o spadek dochodów będący następstwem ewentualnej dekoniunktury eksportowej, zaczęły też śmielej zwracać się ku gorzelnictwu. W przemyśle alkoholowym, obecnym od lat w dobrach magnackich i szlacheckich, przetwarzano najpierw zboża, a później ziemniaki. Te ostatnie u schyłku zaboru zaczęły z wolna przechodzić z ogrodów na pola dworskie, a później i na niwy chłopskie. Wobec niewzruszonych przywilejów propinacyjnych dworu, produkcja gorzałki była jednąz podstawowych gałęzi wytwórczości szlacheckiej, która od opartej na monokulturze gospodarki zbożowej ewoluowała ku ziemniaczano-gorzelniczo-wypasowej. W rezultacie tych przeobrażeń utrwalał się charakterystyczny wizerunek dominium szlacheckiego i przynależnych doń wsi. Stałym elementem pejzażu była oddana w arendę karczma, zwracały poza tym uwagę młyny wodne, gorzelnie i browary - urządzone na ogół prymitywnie i dzierżawione przez Żydów lub szlacheckich sąsiadów zza miedzy ${ }^{4}$.

Przykłady „przedsiębiorczości alkoholowej” płynęły z Zamojszczyzny, gdzie rozwój przemysłu związany był z działalnością kolejnych ordynatów: Aleksandra Augusta i Stanisława Kostki. U schyłku XvIII w. na obszarze

46 T. Mencel, Galicja..., s. 217-218.

47 Cz. Rajca, Gospodarka leśna w Ordynacji Zamojskiej w pierwszejpotowie XIX wieku, „Roczniki Humanistyczne" 1972, t. XX, z. 2, s. 208-209; K. Ajewski, Stanistawa Kostki..., s. 396, 407-408, 426-429.

48 H. Wiercieński, Opis statystyczny..., s. 395, 403; T. Mencel, Galicja..., s. 206; W. Śladkowski, Pod zaborem..., s. 497. 
tych potężnych dóbr pracowało I 4 większych browarów, Is cegielni, 27 gorzelni i Io 4 młyny. Przemysł alkoholowy zorganizowano w tzw. propinacje złożone na ogół z browaru i gorzelni. Na przełomie stuleci propinacji było kilkanaście, a każda z nich posiadała odrębną administrację i kasę. U schyłku stulecia, obok kilkunastu znaczniejszych browarów (w Józefowie, Kraśniku, Krzeszowie, Janowie Lubelskim, Łabuniach, Majdanie Księżpolskim, Szczebrzeszynie, Tarnogrodzie, Tomaszowie, Turobinie, Zamościu i Żdanowie) oraz kilku większych gorzelni (w Batorzu, Łabuniach, Kraśniku, Krzeszowie, Majdanie Księżpolskim i Turobinie) pracowało też kilkadziesiąt drobnych arend rozrzuconych po terenie Ordynacji ${ }^{49}$.

Na początku XIX w. wzniesiono browar w Zwierzyńcu, który szybko zyskał sławę wykraczającą poza sąsiedztwo. W I802 r. postawiono fabrykę tradycyjnego piwa, piwnicę i magazyn zbożowy, zaś w latach I805-1806 wymurowano nowoczesny browar porteru wraz z piwnicami, magazynami, bednarnią do wyrobu i naprawy beczek, wozownią i mieszkaniami dla pracowników. Po zawaleniu sięjednego ze sklepień ( 1806 ) na produkcję napitku „angielskiego” przeznaczono oficynę pałacową. Zwierzyniecką wytwórnię wyposażył częściowo kierownik mechaniki John Mac Donald, pozostałe urządzenia techniczne sprowadzono z Londynu oraz z kuźni w Końskich i Suchedniowie. Produkcją kierował piwowar angielski Mac Millard (ı 806-ı8०8), którego po konflikcie z Ordynacją zastąpił nieznany również z imienia browarnik Kallembach. Stała obsada pracownicza, nie licząc pomocników chłopskich i dorywczych robotników niewykwalifikowanych, wynosiła około trzydziestu osób. W Zwierzyńcu wytwarzano piwo w dwóch gatunkach: zwykłym tzw. „ordynaryjnym” i „dubeltowym” o zwiększonej zawartości alkoholu. Z racji walorów smakowych cieszyło się ono powodzeniem wśród klienteli ordynackiej, ze smakiem pito je także w Lublinie, Puławach i we Lwowie ${ }^{5 \circ}$.

Jak na tle tradycyjnie prowadzonej uprawy roli i roślin oraz rachitycznego przemysłu rolno-spożywczego przedstawiał się kolejny z działów gospodarki wiejskiej - związany z hodowlą zwierząt? W dziedzinie wychowu żywego inwentarza dały się zrazu we znaki zniszczenia będące następstwem wojny i broniącego się w latach 1792-1794 przed obcą przemocą państwa. Znaczące ubytki zanotowano przede wszystkim w pogłowiu koni

49 J. Kasperek, Przemyst rolno-spożywczy w Ordynacji Zamojskiej w drugiej potowie XVIII wieku, „Rocznik Lubelski” 197I, R. XIV, s. 98-99; M. Kozaczka, dz. cyt., s. 84; K. Ajewski, Ordynat..., s. 17; A. Kiper, dz. cyt., s. I8-19.

50 K. Puchała, Opis historyczno-malarski departamentu lubelskiego, Almanach Lubelskina rok I8IS, Lublin [b.d.], s. 21; L. Dembowski, dz. cyt., s. 62; H. Matławska, dz. cyt., s. 177-178; K. Ajewski, Ordynat..., s. 393-395; M. Kozaczka, dz. cyt., s. 88; A. Kiper, dz. cyt., s. 55-56; A. Przegaliński, Zarys dziejów gospodarczych Lubelszczyzny w dobie Księstwa Warszawskiego. Studium z historii regionu w epoce manufaktury i stosunków folwarczno-pańszczyźnianych, Lublin 2020, s. 89-90. 
oraz bydła pociągowego i hodowlanego. W dziale pociągowym przeważały woły - przede wszystkim w uzależnionych od dworu gospodarstwach chłopskich. W ogóle gros bydła, zważywszy na specyfikę gospodarki folwarczno-pańszczyźnianej i konieczność obrabiania ról dziedzica sprzężajem założnym, znajdowała się w rękach włościan. Była to prawidłowość powszechna, charakterystyczna nie tylko dla ziem Lubelszczyzny ${ }^{51}$.

W 1797 r. w trzech interesujących nas blizzej cyrkułach Galicji Zachodniej (chełmskim, józefowskim i lubelskim) wykazano 46258 sztuk wołów pociągowych, sześć lat później (z pominięciem nieuwzględnionego w zestawieniu cyrkułu józefowskiego) - 34408 . W I807 r. w cyrkule lubelskim znajdowało się 26812 wołów roboczych, co w przybliżeniu stanowiło połowę tych zwierząt w zestawieniu z cyrkułem siedleckim (46 434). Nieco inaczej proporcje te kształtowały się w cyrkule zamojskim, gdzie w I807 r. wyszczególniono 19944 sztuki $^{{ }^{2}}$. Woły były zwierzętami tańszymi od koni (w przybliżeniu o jedną trzecią wartości), silnymi, choć pracującymi wolno, łatwymi w utrzymaniu i żywieniu, chętnie też kupowanymi przez rzeźników. Jako zwierzęta opasowe nie cieszyły się jednak na Lubelszczyźnie dużą popularnością - w I 803 r. we wspomnianych trzech cyrkułach wykazano zaledwie 982 okazy, niemal wyłącznie w dobrach szlacheckich. Dla porównania na Podlasiu, biorąc pod uwagę jedynie cyrkuł bialski, opasy liczyły wówczas 20 II zwierząt. Posługiwanie się wołami jako inwentarzem pociągowym opłacało się zwłaszcza w okolicach oddalonych od miast, które były pozbawione udogodnień komunikacyjnych i charakteryzowały się ekstensywną uprawą roli. $\mathrm{Na}$ ich popularność wpływały również czynniki wynikające z austriackiej polityki gospodarczej wobec Galicji Zachodniej. Zwierzęta te nie podlegały bowiem obowiązującym na przełomie wieków ograniczeniom wywozowym, $\mathrm{w}$ tym przede wszystkim restrykcyjnym przepisom celnym i stemplowym ${ }^{53}$.

Poza wołami chłopi chętnie trzymali też krowy (głównie na potrzeby domowe i dla przygotowania nawozu) oraz ze względów prestiżowych niewielkie ilości koni - zwykle po parze na zagrodę. Uważano bowiem, że od liczby krowich i końskich ogonów zależało poważanie i zamożność gospodarza. Ogólnie rzecz biorąc, pogłowie bydła rogatego w cyrkule lubelskim wynosiło w I807 r. 35372 sztuki, czyli najmniej w porównaniu z pozostatymi obwodami Galicji Zachodniej. W cyrkule siedleckim całkowita liczba

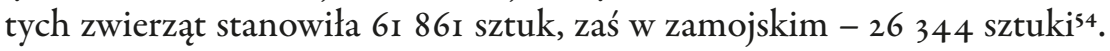

5I H. Grossman, dz. cyt., s. 32.

52 Tamże; T. Mencel, Galicja..., s. 208.

53 W. Pruski, dz.cyt., s. I45-I46; T. Mencel, Galicja..., s. 207-209.

54 H. Grossman, dz. cyt., s. 32; T. Mencel, Galicja..., s. 209. 
Krowy, podobnie jak woły, bytowały u chłopów w katastrofalnych, urągających higienie warunkach. Zwierzęta trzymano w niestarannie ogrodzonych i obrzuconych gliną stajniach, oborach i szopach. Zimą, dla ochrony przed chłodem i wilkami, niektórzy przeprowadzali je do dusznych izb, co wpływało ujemnie na zdrowotność ludzi i bydła. Przegrzany i osłabiony inwentarz wypędzano wiosną na pastwiska, co z kolei było przyczyną powtarzających się zaziębień. Śmiertelność wzmagały powtarzające się zarazy (głównie księgosuszu i motylicy), które dziesiątkowały pogłowie. Niepoślednią rolę odrywało też niskiej jakości pożywienie. Krowy wypasane w lasach, na podmokłych łąkach czy nawet na bagnach i mokradłach jadły kwaśną trawę i piły niezdrową wodę. Zimą karmiono je słomą i sianem. Bydło było nieustannie brudne, pokryte błotem i łajnem. Małe i chude krowy o niskiej mleczności z trudem zaspakajały potrzeby żywieniowe domowników, nie mówiąc już o produkcji mleka, masła, sera i żywca na rynek. Spożycie w miastach i miasteczkach, wobec niewielkiego odsetka biednej w swej masie ludności miejskiej oraz braku prężnych ośrodków handlowych i przemysłowych, było zresztą niewielkie. Konsekwencją takiego stanu rzeczy były też skromne obroty na targach i jarmarkachss.

W dobrach szlacheckich hodowla bydła rogatego nie miała głębszych tradycji i szczególnego znaczenia, niemniej w niektórych większych majątkach utrzymywano stada krów. Bydło folwarczne wypuszczano na ogół w pacht (zajmowali się tym często starozakonni dzierżawcy browarów), nie dbano o rasowy profil obór, nie prowadzono też gospodarki mlecznej. Pozyskiwany z dzierżawy przychód pochodził zazwyczaj z przyrostu naturalnego. Pachciarze spasali zwierzęta odpadkami z browarów i sprzedawali do większych miast. Transakcje takie ułatwiały powiązania arendarzy z żydowskimi rzeźnikami. Poza tak rozumianą hodowlą, niemałe znaczenie miał również przepęd bydła z Ukrainy. Bydło stepowe było tanie i silne, wytrzymałe na dalekie marsze, łatwe w tuczeniu i utrzymaniu. Jego zalety i popularność powodowały, że prowadzenie miejscowych obór okazywało się nieopłacalne - koszt wychowu był bowiem dużo wyższy w porównaniu ze stepowcami. Takie zwierzęta szlachta kupowała więc chętnie na jarmarkach w Łęcznej i Włodawie, karmiła później odpadkami z browarów i zbywała nielegalnie, jako bydło opasowe, do zaboru pruskiego. Na tle tej dość prymitywnej i pozbawionej specjalistycznych podstaw hodowli wyróżniało się kilka majętniejszych dworów, które prowadziły obory ras szwajcarskiej, saskiej i tyrolskiej. Taki charakter miał wychów w dobrach międzyrzeckich książąt Czartoryskich, bydło tyrolskie hodowano też w Końskowoli, 
Maciejowicach i Kocku, wychów „tyrolski” i „szwajcarski” wprowadził do majątków ordynackich S.K. Zamoyski ${ }^{56}$.

Warto w tym miejscu dodać, że władze zaborcze, zważywszy na dostawy żywnościowe dla wojska, starały się wspierać hodowlę bydła i pośrednio handel wewnętrzny. W latach I800-I80I wydano szereg dekretów i przepisów nakazujących odrabianie pańszczyzny lub odbywanie podwód wyłącznie wołami lub końmi. Upowszechniano poza tym normy i zalecenia mające przeciwdziałać szerzącym się chorobom, propagowano zasady higieny w oborach, zachęcano też do mycia zwierząt oraz budowy porządnych obór. Pomimo tej sprzyjającej polityki, hodowla bydła rogatego nie rozwinęła się. Istotną zaporę stanowiły przede wszystkim austriackie ograniczenia wywozowe, które paraliżowały wymianę z zagranicą i zniechęcały do podnoszenia jakości przychówku. Istotną rolę odgrywały też powtarzające się pomory - w tym przede wszystkim zaraza bydlęca, która zdziesiątkowała stada w I $807 \mathrm{r}^{57}$

W dziedzinie wychowu koni wieś ustępowała dworom. W 1797 r. w cyrkułach chełmskim, józefowskim i lubelskim znajdowało się ogółem 2I 858 koni (źrebiąt, ogierów, klaczy i wałachów), na Podlasiu - 31 317. Sześć lat później wartości te wynosiły odpowiednio: 23 I 80 i niepełne 27034 (brak danych z cyrkułu radzyńskiego). Wedle spisu zwierząt gospodarskich przeprowadzonego w 1807 r. w siedmiu obwodach Galicji Zachodniej, w cyrkule lubelskim odnotowano łącznie I2 904 konie (najmniej ze wszystkich cyrkułów galicyjskich), w cyrkule siedleckim - 20 54I, a w cyrkule zamojskim - $25504^{58}$.

U włościan przeważały konie robocze - najczęściej małe, ale silne i niewymagające dużej ilości paszy. Zwierzęta zaprzęgane od młodości do pługów i wozów pracowały jednak ponad siły, szybko starzały się i wyniszczały. Lepsze konie posiadali niektórzy Żydzi, którzy trudnili się furmaństwem, oraz chłopi przewożący zboże i drzewo przeznaczone do spławus9.

W dobrach szlacheckich, wobec poważnych braków w inwentarzu roboczym i skupienia punktu ciężkości na wołach, dominowały konie rasowe. Były to z reguły araby sprowadzane z Galicji Wschodniej i z głębi Rosji. Z tej ostatniej, z powodu protekcjonistycznej i prohibicyjnej polityki cara Pawła I, przepęd na przełomie XVIII i XIX w. był jednak utrudniony. Wobec ubożenia arystokracji i szlachty dał się przy tym zauważyć spadek zapotrzebowania na konie luksusowe (pod wierzch i zaprzęgowe), które powszechnie podziwiano jeszcze w czasach stanisławowskich. Mimo to, zamożniejsi posesjonaci

56 W. Grabski, Historia Towarzystwa Rolniczego 1858-1861, t. I, Warszawa 1904, s. 74-75; T. Mencel, Galicja..., s. 210; K. Ajewski, Ordynat..., s. Io; tenże, Stanistawa Kostki..., s. 419-420.

57 H. Grossman, dz. cyt., s. 32; T. Mencel, Galicja..., s. 209-210, 216.

58 H. Grossman, dz. cyt., s. 32; T. Mencel, Galicja..., s. 208.

59 H. Grossman, dz. cyt., s. 32; T. Mencel, Galicja..., s. 213. 
nabywali je we wspaniałej stadninie orientalnej księcia Hieronima Sanguszki w Sławucie koło Zasławia i w nieodległych Antoninach. Wartościowe okazy pędzono też z Białej Cerkwi Branickich oraz z Jarczowa Działyńskich. Na targach i jarmarkach we Włodawie i Łęcznej kupowano również pochodzące z tych stron półdzikie konie tabunowe - tanie, zahartowane na chłód, zdrowe i wytrzymałe, cenione jako sprzężaj rolniczy i jako konie wyjazdowe. Dobrze prowadzonych stadnin, wobec braku pastwisk i łąk, było jednak na Lubelszczyźnie niewiele. W ostatnich latach panowania austriackiego zasłużoną sławę, która obrosła później legendą, zdobyło stado opolskie Rozalii z Lubomirskich Rzewuskiej. Stadnina zawdzięczała swój rozkwit „pustynnym” ekspedycjom męża arystokratki, Wacława „Emira” Rzewuskiego, który pędził zwierzęta wprost z Arabii. W latach późniejszych „Emir” opuścił żonę i osiadł w rodzinnym Sawraniu na Wołyniu, gdzie poświęcił się hodowli arabów. W cyrkule zamojskim pionierem wychowu koni rasowych był S.K. Zamoyski, który, podobnie jak Czartoryscy w Puławach, pasjonował się pełnej krwi „anglikami”. Wsparty wiedzą zdobytą w czasie francuskich i angielskich peregrynacji, na początku XIXw., najpierw w maciejowickim Podzamczu, a później w Michalowie koło Szczebrzeszyna założył stadninę, która cieszyła się znakomitą reputacją i zapoczątkowała związki folblutów z Lubelszczyzną. Stado miało charakter wybitnie reprezentacyjny - ordynat posiadał angielskie cugi i eleganckie zaprzęgi, których używał podczas swych licznych wojaży. Konie z Michalowa służyły również pod wierzch - np. w czasie urządzanych w Puławach rodzinnych przejażdżek i wyścigów ${ }^{60}$.

W dziedzinie hodowli nierogacizny, która za czasów austriackich nie podlegała ograniczeniom wywozowym, dominowali chłopi. Wraz z upływem lat skupili oni w swoich rękach wychów dawnej odmiany krajowej - dość prymitywnej, ale zdrowej, żywotnej i niewybrednej, która dawała zdatną do długotrwałego użytku słoninę oraz mięso doskonałe do trwałych wędlin $\mathrm{i}$ innych przerobów. Dwory, wobec niewielkiego zapotrzebowania na mięso w miastach, trzymały świnie, prowadzone z resztą bez należytego kierunku i dbałości o poprawę rasy, prawie wyłącznie na własne potrzeby. Podobnie było w zagrodach chłopskich. Jedynie część włościan, mieszkających przy

60 Antoniny, [w:] Stownik Geograficzny Królestwa Polskiego i innych krajów stowiańskich, t. I, red. F. Sulimierski, B. Chlebowski, W. Walewski, Warszawa ı880, s. 42; Stawuta, [w:] Stownik..., t. x, red. B. Chlebowski, W. Walewski, Warszawa 1889, s. 794; L. Dembowski, dz. cyt., s. I89-190; T.Żychliński, Ztota ksiegga szlachty polskiej, R. v, Poznań ı883, s. 304-305; H. Wiercieński, Opis statystyczny..., s. 283-284; W. Mroziński, Konie, [w:] Księga Pamiątkowa Wystaw Lubelskich, Warszawa 1902, s. 24; W. Pruski, dz. cyt., s. 165-167, 170, 175-180, 184, I88; tenże, Dzieje wyścigów i hodowli koni petnej krwi w Polsce, Warszawa 1970, s. 21-22; S. Deskur, Hodowla koni $w$ Polsce, [w:] Dziedzictwo. Ziemianie polscy i ich udziat w życiu narodu, red. T. Chrzanowski, Kraków 1995, s. 73-74; K. Ajewski, Stanistawa Kostki..., s. 420-423; K. Jastrzębski, Opole Lubelskie. Historia miasta i powiatu, t. II: 1663-1870, Warszawa-Puławy 2009, s. 335-339. 
spławnych rzekach, sprzedawała trzodę flisakom płynącym ze zbożem i drzewem do Gdańska. Nierogacizna, zarówno u chłopów jak i na folwarkach, bytowała w niezmiernie prymitywnych warunkach. Zwierzęta przebywały głównie na polach i w lasach, rzadziej w chlewach, do których zaganiano je zimą, tj. w czasie, kiedy śnieg, gołoledź lub inne przeszkody uniemożliwiały znalezienie pożywienia. Świnie, puszczane na żer i krzyżujące się w lasach z dzikami, stanowiły plagę rolnictwa. Grasując po okolicznych terenach wyrządzały szkody na polach i łąkach, siały też spustoszenie w ogrodach warzywnych wsi i dworu ${ }^{6}$.

Niemałą rolę w produkcji zwierzęcej Lubelszczyzny odgrywała hodowla owiec - przede wszystkim grubowełnistych zwanych potocznie świniarkami. Wychowem tych zwierząt, mającym na ziemiach polskich długie tradycje sięgające czasów wczesnonowożytnych, zajmowali się przede wszystkim chłopi, ale też i dwory. Włościanie pozyskiwali skóry na kożuchy, wełna służyła do tkania samodziałowego sukna, pewną część utkanych motków oddawano dworom w ramach powszechnie obowiązujących danin w naturze. W niektórych miejscach, zwłaszcza na południu Lubelszczyzny, gdzie chłopi powszechniej zajmowali się sukiennictwem, zbywano surową wełnę lub gotowy materiał pośrednikom żydowskim, rzemieślnikom oraz właścicielom nielicznych manufaktur. Owce, podobnie jak pozostały inwentarz, bytowały w nienajlepszych warunkach sanitarnych. Począwszy od wiosny do później jesieni wypasano je na ścierniskach, ugorach i na odłogach, zimązaganiano do owczarni - niewielkich i prosto urządzonych. Wraz z przyrostem naturalnym pomieszczenia te okazywały się jednak zbyt małe. Zwierzęta, karmione wówczas słomą, niewielkie i słabe, leżały ciasno w wilgoci i gnoju. Nieco więcej uwagi poświęcały owcom dwory - zwłaszcza w tych dobrach, gdzie zajmowano się hodowlą hiszpańskich merynosów (m.in. w Kocku A. Jabłonowskiej i w Bochotnicy Małachowskich), owiec angielskich (we Wronowie Ernesta Goltza) i tzw. owiec „polskich”, „krymskich” i „węgierskich” w Niedzieliskach, Sitańcu i Czernięcinie należących do Ordynacji Zamojskiej. W tej ostatniej, pomimo pięknych tradycji sięgających czasów Jana Zamoyskiego i dość licznego pogłowia (w I806 r. 2796 sztuk), na skutek nadużyć ze strony administracji i oficjalistów, hodowla przeżywała jednak kryzys. Z czasem przezwyciężył go S.K. Zamoyski, rozwijając wychów wysokogatunkowych merynosów elektoralnych i owiec uszlachetnionych, które dostarczały surowca dla przemystu sukienniczego. Wraz z upływem lat na ziemiach polskich szczególnym powodzeniem zaczęły cieszyć się właśnie

6I H. Wiercieński, Opis statystyczny..., s. 299; Stan hodowli trzody chlewnej, „Gazeta Rolnicza”, 1902, nr 25, s. 419; W. Pruski, Hodowla..., s. 226-227, 232, 239; T. Mencel, Galicja..., s. 215. 
cienkowełniste elektorały. Ich popularność była związana z żywiołowym rozwojem owczarstwa w Saksonii i Austrii. Począwszy od lat siedemdziesiątych XVIII w. postępowi rolnicy zaczęli stamtąd sprowadzać owce hiszpańskie, które później nabywano także w Czechach oraz na Węgrzech, Morawach i na pruskim Śląsku ${ }^{62}$.

Na popularność owczarstwa wpływało wiele czynników. W niemałym stopniu decydowała polityka władz austriackich, które wyłączyły owce z zakazów eksportowych. Początkowo zezwalano na wywóz bezcłowy do dziesięciu sztuk, zaś z końcem 1799 r. rozszerzono limity do stu, po uprzednim opłaceniu cła. Pierwszorzędne znaczenie miało rosnące zapotrzebowanie na wełnę i związane z popytem ceny. Te ostatnie, w porównaniu z wartością rynkową pozostałych wytworów gospodarki rolno-hodowlanej, kształtowały się na ogółbardzo korzystnie i nie podlegały większym wahaniom. Nie do przeceniania był wreszcie fakt, że hodowla owiec, doskonale zestrojona z trójpolową gospodarką zbożową, nie wymagała znaczniejszych nakładów, a transport wełny - produktu lekkiego, niepsującego się przy magazynowaniu, łatwego do pakowania i przewożenia - nie nastręczał trudności, był więc też opłacalny. Wraz z upływem lat pogłowie owiec rosło. Wedle niepełnych danych pochodzących z 1803 r. w cyrkułach chełmskim i józefowskim wykazano ogółem 48500 owiec ordynaryjnych i uszlachetnionych, w cyrkule bialskim - IO2 486. Cztery lata później w cyrkule lubelskim znajdowało się 38 991 tych zwierząt, co mniej więcej odpowiadało średniej w Galicji Zachodniej, w cyrkule zamojskim - 2I 457. Dla porównania w obwodzie siedleckim pogłowie owiec liczyło wówczas 39907 okazów, w bialskim - $96809^{63}$.

\section{Zakończenie}

Partią tekstu dotyczącą owczarstwa kończymy nasze rozważania. Omówione wyżej przejawy aktywności gospodarczej wsi i dworu nie skłaniają do wyciągania krzepiących wniosków. Utrzymywanie się na ziemiach międzyrzecza Wisły i Bugu zacofanej i zakonserwowanej przez zaborcę struktury społeczno-ekonomicznej w rolnictwie nie dostarczało bowiem bodźców stymulujących rozwój gospodarczy regionu. Wyznacznikiem stagnacji był folwark pańszczyźniany oraz niesamodzielne, ubogie i niezdolne do produkcji towarowej chłopstwo. Rolnictwo Lubelszczyzny na przełomie stuleci, pomimo dobrych warunków naturalno-glebowych i sprzyjającej koniunktury

\footnotetext{
62 H. Wiercieński, Opisstatystyczny..., s. 294; W. Grabski, Historia Towarzystwa..., s. 73; W. Pruski, Hodowla..., s. 43-50; J. Bartyś, Hodowla..., s. 457-459, 474-475; T. Mencel, Galicja..., s. 213-2I4; K. Ajewski, Stanistawa Kostki..., s. 418-419.

63 H. Grossman, dz. cyt., s. 32; T. Mencel, Galicja..., s. 214.
} 
gospodarczej, zmagało się z różnymi niedogodnościami, które były pochodną wieloletnich zaniedbań. W epokę zaboru austriackiego wkroczyła wieś tradycyjna, czyli folwarczno-pańszczyźniana, z wszelkimi konsekwencjami i obciążeniami wynikającymi z zależności stanowych i prymitywnego gospodarowania. Pod hegemonią Habsburgów (prowadzących wobec Galicji wzmożoną działalność eksploatacyjną opartą na drenażu fiskalnym, zaopatrzeniu żywnościowym i materiałowym dla wojska oraz poborze rekruta) nie zanotowano w tych kwestiach żadnych istotnych postępów. Położenie chłopów, wobec odwrotu od reform terezjańsko-józefińskich, determinowały w dalszym ciągu: poddaństwo, rozliczne robocizny i samowola sądownicza dziedziców. Dominia szlacheckie trwały przy ekstensywnej uprawie zbóż, produkcji alkoholu i hodowli żywego inwentarza, którą prowadzono bez należytej dbałości o wychów i kalkulację finansową - głównie na potrzeby własne i w celu zapewnienia chłopom załogi. Więcej uwagi poświęcano na pewno hodowli owiec (owczarstwo było także popularne wśród włościan), ale i tu wychów rasowy stanowił domenę nielicznych dziedziców. Ożywcze prądy płynęły wprawdzie z Zamojszczyzny - pod patronatem S.K. Zamoyskiego inicjowano wszak różne prace zmierzające do podnoszenia poziomu gospodarowania i promocji postępowej myśli agronomicznej, ale usiłowania te nie przekraczały granic cyrkułu lub spotykały się z obojętnością szlachty. W epoce zaboru austriackiego Lubelszczyzna, pomimo dobrych warunków terenowych, należała więc nadal do zacofanej, stojącej nisko pod względem kultury rolnej części ziem polskich. W takiej też kondycji wkraczała w czas burzliwych wydarzeń I 809 r., kiedy to jej losy zostały ściśle splecione z dziejami Księstwa Warszawskiego.

\section{Bibliografia}

\section{Źródła drukowane}

Dembowski L., Moje wspomnienia, t. I, Petersburg 1898.

„Gazeta Rolnicza” 1902

Korzon T., Odrodzenie w upadku. Wybór pism historycznych, oprac. M.H. Serejski, A.F. Grabski, Warszawa 1975.

Koźmian K., Pamiętniki, t. I, oprac. J. Willaume i in., Wrocław-Warszawa-Kraków-Gdańsk 1972.

Spis ludności diecezji krakowskiej zr. I787, wyd. J. Kleczyński, „Collectanea ex Archivo

Collegii Historici”, t. viI, Kraków I894.

Wiercieński H., Pamiętniki, oprac. A. Zajączkowski, Lublin 1973.

\section{Opracowania}

Ajewski K., Ordynat Stanistaw Kostka Zamoyski oczami Anglika widziany, „Mazowieckie Studia Humanistyczne" 2005, nr I-2. 
ANDRZEJ PRZEGALIŃSKI Zarys stosunków rolniczych Lubelszczyzny na przełomie XVIII i XIX wieku...

Ajewski K., Stanistawa Kostki Zamoyskiego życie i dziatalność $1775-1856$, Warszawa 2010.

Aleksandrowicz A., Putawy w latach I796-I83I, [w:] Z przesztości kulturalnej Lubelszczyzny, oprac. A. Aleksandrowicz, R. Gerlecka, W. Śladkowski, S. Tworek, Lublin 1978.

Aleksandrowicz A., Wartości chrześcijańskie w Putawach Czartoryskich (Na przyktadzie twórczości księżnej Izabeli z Flemingów Czartoryskiej), [w:] Przestrzeń chrześcijańska w kulturze polskiej. Polska i Putawy „na gtównym szlaku duchowych dziejów”, red. T. Giergiel, Puławy 2017.

Baczkowski M., Czy Kraków mógt zostaćstolica Galicji na początku XIX wieku?, „Zeszyty Naukowe Uniwersytetu Jagiellońskiego", Prace Historyczne, 2009 , z. 136.

Banaś B., Kurów jako ośrodek administracji. Od lokacji do 1939 roku, Kurów 2011.

Bardach J., Leśnodorski B., Pietrzak M., Historia ustroju i prawa polskiego, wyd. piąte, Warszawa 2005.

Bartyś J., Hodowla owiec rasowych w dobrach Ordynacji Zamojskiej, „Studia z Dziejów Gospodarstwa Wiejskiego", t. II, red. J. Leskiewiczowa, Wrocław 1959.

Bartyś J., Początki mechanizacji rolnictwa polskiego, Wrocław-Warszawa-Kraków 1966.

Bartyś J., Sukiennictwo w ordynacji zamojskiej w I potowie XIX wieku, „Przegląd Historyczny" 1958, nr 3.

Bogucka M., Dzieje kultury polskiej do 1918 roku, Wrocław-Warszawa-Kraków-Gdańsk-Łódź 1987.

Bondyra W., Stownik historyczny miejscowości województwa zamojskiego, Lublin-Zamość 1993.

Boreczek K.A., Kurów. Od początku XVIII do potowy XX wieku. Częśćpierwsza I700-I9I8, Kurów 1996.

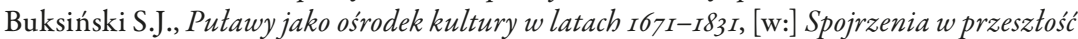
Lubelszczyzny, red. K. Myśliński i A.A. Witusik, Lublin 1974.

Czapliński W., Zarys dziejów Polski do roku I864, Kraków 1985.

Czermiński F., O Towarzystwie Kredytowym Ziemskim w Królestwie Polskim, „Biblioteka Warszawska" 1864 , t. III.

Czernicki K., Chetm przesztość i pamiątki, Chełm 1936.

Czubaty J., Księstwo Warszawskie (I807-1815), Warszawa 2011.

Ćwik W., Reder J., Lubelszczyzna. Dzieje rozwoju terytorialnego, podziatów administracyjnych i ustroju wtadz, Lublin 1977.

Demska-Trębacz M., Muzyczny pejzaż Lubelszczyzny. Dworki i dwory, Lublin 2005.

Deskur S., Hodowla koni w Polsce, [w:] Dziedzictwo. Ziemianie polscy i ich udziat w życiu narodu, red. T. Chrzanowski, Kraków 1995.

Duda J., Towarzystwo Rolnicze Hrubieszowskie. Staszicowski model pomocy gospodarczej dla wsi, Lublin 1994.

Feduszka J., Nowoczesne metody gospodarowania w dobrach Ordynacji Zamojskiej w początkach XIX wieku - prekursorzy i propagatorzy, „Roczniki Naukowe Stowarzyszenia Ekonomistów Rolnictwa i Agrobiznesu" 2005, t. vII, z. 7.

Geografia albo doktadne opisanie Królestw Galicji i Lodomerii, Lwów I858.

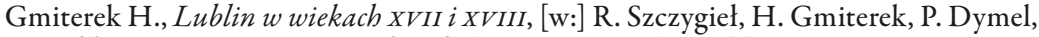
Lublin. Dzieje miasta, t. I: OdVI do końca XVIII wieku, Lublin 2008.

Gołębiowska Z., Dwór a modernizacja wsi polskiej na przyktadzie ośrodka putawskiego

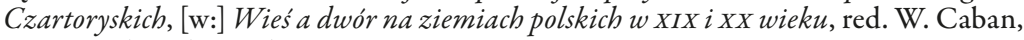
M.B. Markowski, Kielce 1999.

Gołębiowska Z., Mecenat kulturalny Izabeli i Adama Kazimierza Czartoryskich, [w:] Ziemiaństwo na Lubelszczyźnie, red. R. Maliszewska, Kozłówka 2003.

Gołębiowska Z., Przybysze z Wysp Brytyjskich i ich potomkowie między Pilica a Bugiem wXVIII-XIX wieku, [w:] Ważna obecność. Przedstawiciele państw i narodów europejskich wśród mieszkańców międzyrzecza Bugu i Pilicy w XVIII-XIX wieku, red. A. Górak i K. Latawiec, Radzyń Podlaski-Radom 2006.

Grabski W., Historia Towarzystwa Rolniczego 1858-1861, t. I, Warszawa 1904.

Grabski W., Historia wsi w Polsce, Warszawa 2004. 
ANDRZEJ PRZEGALIŃSKI Zarys stosunków rolniczych Lubelszczyzny na przełomie XVIII i XIX wieku...

Grodziski S., Habsburgowie, [w:] Dynastie Europy, red. A. Mączak, Wrocław-Warszawa-Kraków 1997.

Grodziski S., Kozłowski E., Polska zniewolona 1795-1806, Warszawa 1987.

Grossman H., Struktura spoteczna i gospodarcza Księstwa Warszawskiego na podstawie spisów 1808-1810 roku, „Kwartalnik Statystyczny”, t. II, Warszawa 1926.

Grynwaser H., Kwestia wtościańska i ruch wtościan w Królestwie Polskim w pierwszej potowie $X I X$ wieku, Warszawa 1935.

Herbst S., $Z$ dziejów wojskowych powstania kościuszkowskiego 1794 roku, Warszawa 1983.

Historia Polski. Polska 1586-1831, t. 6, Warszawa 2007.

Ihnatowicz I., Od rozbiorów do pierwszej wojny światowej, [w:] I. Ihnatowicz, A. Mączak, B. Zientara, J.Żarnowski, Spoteczeństwo polskie od X do XX wieku, wyd. trzecie, Warszawa 1996.

Ihnatowicz I., Biernat A., Vademecum do badań nad historia XIX $i$ XX wieku, Warszawa 2003.

Inglot S., Historia spoteczno-gospodarcza chtopów polskich w zaborze austriackim, [w:] Historia chtopów polskich, t. II: Okres zaborów, red. S. Inglot, Warszawa 1972.

Janowicz L., Zarys rozwoju przemystu w Królestwie Polskim, Warszawa 1907.

Jastrzębski K., Opole Lubelskie. Historia miasta i powiatu, t. II: 1663-1870, Warszawa-Puławy 2009.

Jezierski A., Leszczyńska C., Historia gospodarcza Polski, Warszawa 1998.

Kaliński J., Historia gospodarcza XIX $i_{X X}$ w., wyd. drugie, Warszawa 2008.

Kasperek J., Przemyst rolno-spożywczy w Ordynacji Zamojskiej w drugiejpotowie XVIII wieku, „Rocznik Lubelski” 1971.

Kiper A., Anglicy w Ordynacji Zamojskiej w XIX wieku, „Rocznik Kolbuszowski” 2012.

Kołodziejczyk R., Gradowski R., Zarys dziejów kapitalizmu w Polsce, Warszawa 1974.

Korzon T., Wewnętrzne dzieje Polski za Stanistawa Augusta (I764-I794), t. II, Warszawa 1897.

Kostrowicka I., Landau Z., Tomaszewski J., Historia gospodarcza Polski XIX $i$ XX wieku, Warszawa 1985 .

Kozaczka M., Poczet ordynatów Zamoyskich, Lublin 2004.

Krzos K., Z księciem Józefem w Galicji w I809 roku. Rzad Centralny Obojga Galicji, Warszawa 1967.

Kumor B., Spisy ludności Galicji z lat I800-1808, „Przeszłość Demograficzna Polski” 1972, t. v.

Leskiewiczowa J., Zamiast wstępu, [w:] Ziemiaństwo polskie 1795-1945, red. J. Leskiewiczowa, Warszawa 1985 .

Leśnodorski B., Historia i wspótczesność, Warszawa 1967.

Ludkiewicz Z., Polityka agrarna, wyd. czwarte, Poznań I92I.

Łepkowski T., Polska - narodziny nowoczesnego narodu, Warszawa 1967.

Łopaciński H., Podziaty administracyjne teraźniejszej guberni lubelskiej w różnych czasach, [w:] Pamiętnik Lubelski. Kalendarz Ilustrowany na rok 1904, Lublin 1904.

Matławska H., Zwierzyniec, Zwierzyniec i991.

Mazurkiewicz J., Lublin w okresie reform (I764-1795), [w:] Dzieje Lublina. Próba syntezy, t. I, red. J. Dobrzański, J. Kłoczowski i J. Mazurkiewicz, Lublin 1965.

Mazurkiewicz J., W czasach stanistawowskich, [w:] Dzieje Lubelszczyzny, t. I, red. T. Mencel, Warszawa 1974.

Mencel T., Ciężary wojskowe Galicji Zachodniej w czasie wojen Austrii przeciw Francji w latach 1796-I809, „Annales Universitatis Mariae Curie-Skłodowska”, Sectio F, vol. 29, 1974.

Mencel T., Galicja Zachodnia 1795-I809. Studium z dziejów ziem polskich zaboru austriackiego po III rozbiorze, Lublin 1976.

Mencel T., Poczatki organizacji Galicji Zachodniej w latach $1795-1796$, „Kwartalnik Historyczny" $1970, \mathrm{nr} 2$.

Mencel T., Wieśpańszczyźniana w Królestwie Polskim, Lublin 1988.

Mierzwiński H., Dziatalność opiekuńczo-wychowawcza księżnej Anny Pauliny z Sapiehów Jabtonowskiej na tle dziejów, „Szkice Podlaskie” 2002, t. x.

Mierzwiński H., Księżna Anna Paulina z Sapiehów Jabtonowska (I728-180o), „Szkice Podlaskie" 1999, t. VII. 
ANDRZEj PRZEGALIŃSKI Zarys stosunków rolniczych Lubelszczyzny na przełomie XVIII i XIX wieku...

Mroziński W., Konie, [w:] Księga Pamiątkowa Wystaw Lubelskich, Warszawa 1902.

Opas T., Reder J., Betżyce. Studia i szkice z dziejów miasta, Lublin 1997.

Orłowski R., Problemy spoteczno-gospodarcze Lubelszczyzny XVII i XVIII stulecia, „Annales Universitatis Mariae Curie-Skłodowska", Sectio F, vol. 32, 1977.

Prażmowska T., Dzieje trzech rozbiorów Polski oraz ruchu narodowego w XIX w. (poprzedzone zarysem panowania domu saskiego), Warszawa I9Iо.

Pruski W., Dzieje wyścigów i hodowli koni petnej krwi w Polsce, Warszawa 1970.

Pruski W., Hodowla zwierząt gospodarskich $w$ Królestwie Polskim w latach I8I5-I9I8, t. I, Warszawa 1967.

Przegaliński A., Dwór ziemiański na Lubelszczyźnie w epoce przemian gospodarczych i spotecznych. Dzieje dóbr Snopków w XIX i w I potowie XX wieku, Lublin 2016.

Przegaliński A., Gdy życie stato siępasją, a pasja byta muzyką. Studium z dziejów zatożenia patacowo-parkowego w Gościeradowie, „Teka Komisji Historycznej” 2010, t. vir.

Przegaliński A., Zarys dziejów gospodarczych Lubelszczyzny w dobie Księstwa Warszawskiego. Studium z historii regionu wepoce manufaktury i stosunków folwarczno-pañszczyźnianych, Lublin 2020.

Puchała K., Opis historyczno-malarski departamentu lubelskiego, [w:] Almanach Lubelski na rok I8Is, Lublin [b.d.].

Rajca Cz., Gospodarka leśna w Ordynacji Zamojskiej w pierwszej potowie XIX wieku, „Roczniki Humanistyczne” 1972, t. XX, z. 2.

Rusiński W., Rozwój gospodarczy ziem polskich w zarysie, Warszawa 1963.

Rusiński W., Zarys historii gospodarczej powszechnej. Czasy nowożytne i najnowsze (I500-1939), Warszawa 1970.

Rzepniewska D., Problematyka ziemiańska w aktach hipoteki dóbr ziemskich, [w:] Ziemiaństwo polskie 1795-1945, red. J. Leskiewiczowa, Warszawa 1985.

Serczyk W.A., Katarzyna II, Wrocław 2004.

Stownik Geograficzny Królestwa Polskiego i innych krajów stowiańskich, t. I, red. F. Sulimierski, B. Chlebowski, W. Walewski, Warszawa I880.

Stownik Geograficzny Królestwa Polskiego i innych krajów stowiańskich, t. x, red. B. Chlebowski, W. Walewski, Warszawa I889.

Smoleński W., Konfederacja targowicka, Kraków 1903.

Szczygieł R., Od lokacji do upadku szlacheckiej Rzeczypospolitej, [w:] Dzieje Końskowoli, red. R. Szczygieł, Lublin 1988.

Szymański Z., Gospodarka Lubelszczyzny w czasach stanistawowskich, „Zeszyty Naukowe WSEI", ser. E, 20I4, z. 9.

Szyndler B., Powstanie kościuszkowskie 1794, Warszawa 1994.

Szyszka A., Szyszka B., Mecenat oświatowy Stanistawa Kostki Zamoyskiego, „Przegląd Historyczno-Oświatowy" 2010, z. 3-4.

Śladkowski W., Pod zaborem austriackim, w Księstwie Warszawskim i Królestwie Polskim I795-I83I, [w:] Dzieje Lubelszczyzny, t. I, red. T. Mencel, Warszawa 1974.

Śladkowski W., Po utracie niepodlegtości I795-183I, [w:] Z przesztości dalekiej i bliskiej. Szkice zdziejów Lubelszczyzny, red. A. Koprukowniak i W. Śladkowski, Lublin I980.

Śladkowski W., Wepoce zaborów, [w:] T. Radzik, W. Śladkowski, G. Wójcikowski, W. Wójcikowski, Lublin. Dzieje miasta, t. II: XIX $i_{X X}$ wiek, Lublin 2000.

Śladkowski W., W latach zaborów i nadziei wolności 1795-1831, [w:] Z przesztości kulturalnej Lubelszczyzny, oprac. A. Aleksandrowicz, R. Gerlecka, W. Śladkowski, S. Tworek, Lublin 1978.

Ślusarek K., Blaski i cienie reform agrarnych w XIX-wiecznej Galicji, [w:] Wolni i uwtaszczeni. Chtopi a przemiany spoteczne, gospodarcze i polityczne w Europie Wschodniej w XIX ina poczattkuXX wieku, red. D. Michaluk, Ciechanowiec 2017.

Świętochowski A., Historia chtopów polskich w zarysie, t. II: W Polscepodlegtej, Lwów-Poznań 1928.

Wiercieński H., Opis statystyczny guberni lubelskiej, Warszawa 1901.

Willaume J., $Z$ dziejów wsi lubelskiej przed uwtaszczeniem, „Annales Universitatis Mariae Curie-Skłodowska”, Sectio F, vol. X, 1955. 
Wiśniewski S., Pod rządami zaborców 1795-I9I8, [w:] Dzieje Końskowoli, red. R. Szczygieł, Lublin 1988.

Wróbel-Lipowa K., Na przetomie epok. Hrubieszów w Galicji Wschodniej (I772-I809), [w:]

Dzieje Hrubieszowa, t. I: Od pradziejów do IgI8 roku, red. R. Szczygieł, Hrubieszów 2006.

Zahorski A., Powstanie kościuszkowskie 1794, [w:] S. Kieniewicz, A. Zahorski, W. Zajewski, Trzy powstania narodowe: kościuszkowskie, listopadowe, styczniowe, Warszawa 2000.

Ziółek E.M., W okresie rozbiorów i zaboru austriackiego, [w:] Lublin. 700 lat dziejów miasta, red. G. Figiel, R. Szczygieł, W. Śladkowski, Lublin 2017.

Żychliński T., Ztota ksiega szlachty polskiej, Poznań I883.

\section{Źródła internetowe}

Czajka G., Myśl ustrojowa i spoteczna Wojciecha Gutkowskiego, Kraków 2009, mps pracy magisterskiej. Dostępna w Internecie: http://www.knhd.law.uj.edu.pl/documents/3035628/6cdd2a32-f $4 \mathrm{f}_{3}-4 \mathrm{de} 8-9 \mathrm{a} 36-3 \mathrm{ar} 870 \mathrm{f}_{2} \mathrm{cce} 3$.

Streszczenie: Artykuł stanowi próbę opisu dziejów gospodarczych Lubelszczyzny postrzeganych przez pryzmat rolnictwa w schyłkowym okresie państwa polskiego i przede wszystkim w epoce zaboru austriackiego (1795-1809). Poruszana w tekście problematyka, poprzedzona rysującym szerszy kontekst polityczny Wprowadzeniem, koncentruje się wokół spraw związanych z kondycją gospodarczą ówczesnej wsi i dworu. Poza niezbędnymi komponentami dotyczącymi produkcji roślinnej i hodowli żywego inwentarza, w narracji uwzględniono także zagadnienia odnoszące się do położenia prawnego, charakterystyki społecznej i stanowej oraz ścisłych zależności między światami chłopskiej chałupy i szlacheckiego dworu. Artykuł o układzie chronologiczno-problemowym ma charakter syntetyczny zwieńczony zwięzłym Zakończeniem. Mam nadzieję, że w takiej postaci może on stanowić przyczynek do badań porównawczych uwzględniających obie Galicje (Starą i Nową) oraz pozostałe zabory na przełomie XVIII i XIX w. Poniższy tekst można też traktować jako źródło przystępnie podanej wiedzy, którą autor adresuje do szerszego grona Czytelników.

Słowa klucze: dwór szlachecki, historia gospodarcza, Lubelszczyzna, rolnictwo, wieś, zabór austriacki

Summary: The article is an attempt to describe the economic history of the Lublin region perceived through the prism of agriculture in the late period of the Polish state and, above all, during the Austrian Partition (1795-1809). The issues discussed here, preceded by the introductory outline of a broader context, focus on matters related to the economic condition of the village and manor at that time. In addition to the necessary components for crop production and livestock farming, the text also includes issues focused on legal position, social and state characteristics, and the close relationship between the worlds of a peasant cottage and a noble court. The chronological-problem article is synthetic. I hope that in this form the article may contribute to comparative research taking into account both Galicia (Old and New) and other partitions at the turn of the eighteenth and nineteenth centuries. It should also be a source of easily accessible knowledge, which the author addresses to a wider group of readers.

Keywords: gentry court, economic history, Lublin region, agriculture, village, Austrian Partition 